
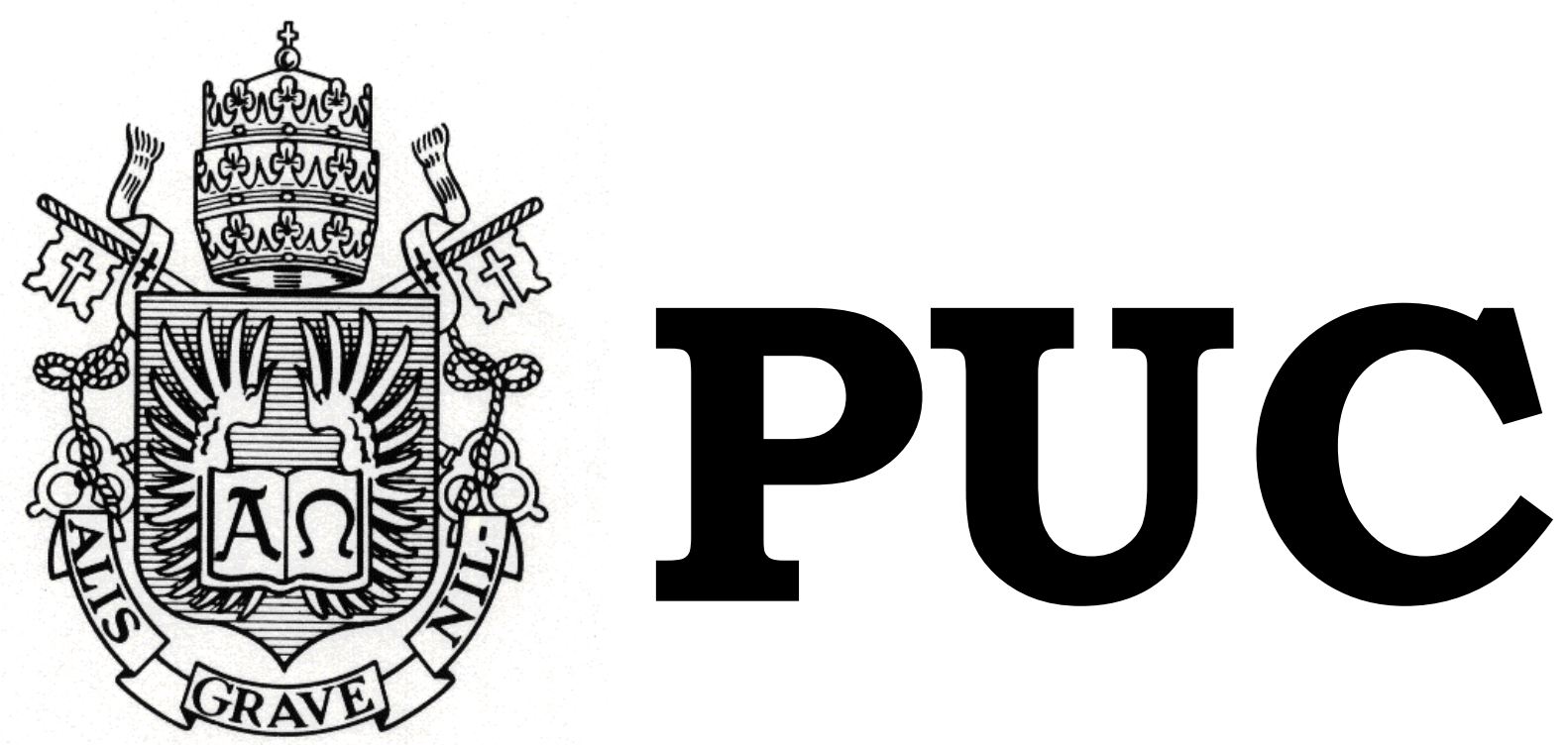

DEPARTAMENTO DE DIREITO

\title{
DIREITO DAS SUCESSÕES: COLAÇÃO
}

por

\author{
MigUel ANTONIO A. C. CASANOVA
}

ORIENTADOR(A): Álvaro Piquet Carneiro Pessôa dos Santos

\section{2}

PONTIFÍCIA UNIVERSIDADE CATÓLICA DO RIO DE JANEIRO

RUA MARQUÊS DE SÃO VICENTE, 225 - CEP 22453-900

RIO DE JANEIRO - BRASIL 


\title{
DIREITO DAS SUCESSÕES: COLAÇÃO
}

por

\section{MIGUEL ANTONIO A. C. CASANOVA}

\author{
Monografia apresentada ao \\ Departamento de Direito da \\ Pontificia Universidade Católica do \\ Rio de Janeiro (PUC-Rio) para a \\ obtenção do Título de Bacharel em \\ Direito.
}

Orientador(a): Álvaro Piquet Carneiro Pessôa dos Santos 
À minha avó Wupps, que me ensinou que a morte não é o fim dos laços humanos. 


\section{Resumo.}

O presente estudo tem como objetivo fundamental a análise do instituto da colação. A colação é o ato pelo qual os herdeiros descendentes de mesma classe, que concorrem à sucessão do ascendente comum, reúnem ao monte partível quaisquer liberalidades que dele em vida receberam, sob pena de sonegados, para que sejam conferidas e igualadas as respectivas legítimas (CC, arts. 2.002 e 2.003). A justificativa da exigência da colação funda-se na igualdade entre os descendentes e na antecipação da herança.

No direito pátrio a colação possui três pressupostos. (i) A colação é cabível apenas na sucessão legítima; (ii) Existência de co-herdeiros necessários, descendentes; (iii) A ocorrência de uma liberalidade feita em vida, pelo ascendente, em favor de descendente ou do cônjuge sobrevivente.

Existem dois modos de realização da colação, quais sejam, por estimação e em substância (CC, art. 2.003, § único). Quanto ao valor dos bens doados, existem duas formas para calculá-los: para efeito de compensação, que é a regra geral, o Código Civil adota como parâmetro para apurar o valor do bem, a data em que a doação foi realizada, é claro, com a devida correção monetária (CC, arts. 2.003, § único e 2.004). Este sistema só é quebrado em caso de redução, que exige a restituição do excesso em espécie ou segundo o valor ao tempo da abertura da sucessão (CC, art. 2.007, § 2º).

\section{Palavras-chave.}

Direito das Sucessões

Colação

Igualdade das legítimas 


\section{SUMÁRIO.}

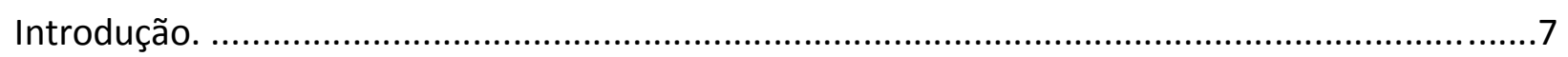

Capítulo I - Direito das Sucessões. Breves Considerações. .....................................................9

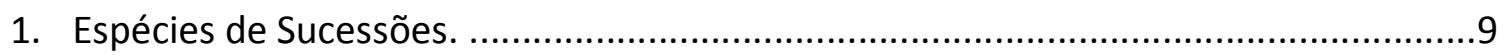

2. Herdeiros necessários. A legítima e a porção disponível. .......................................10

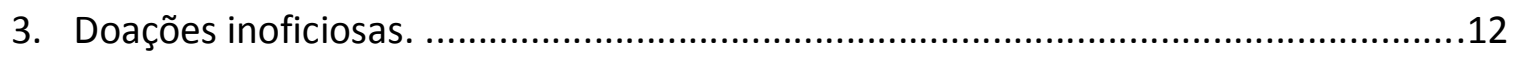

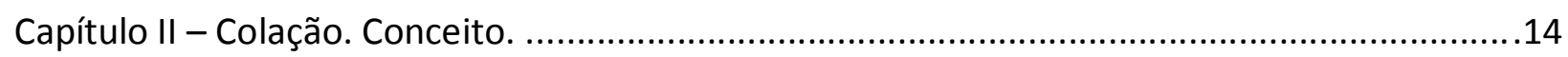

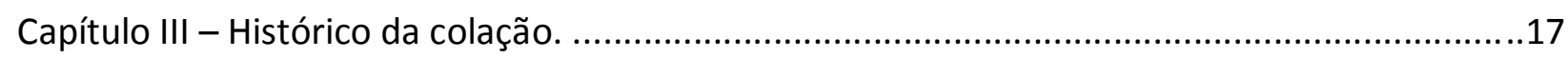

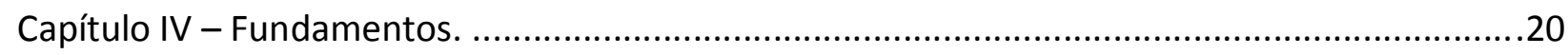

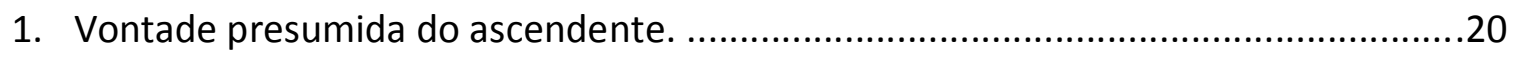

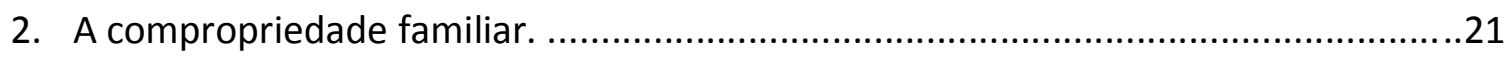

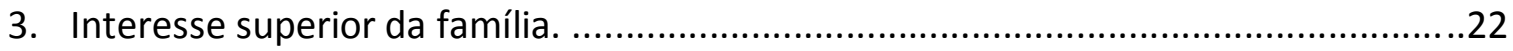

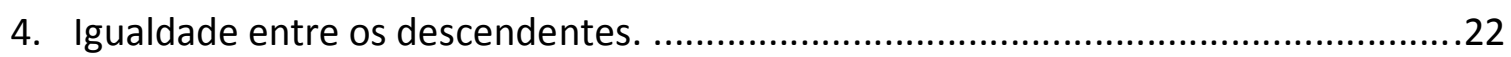

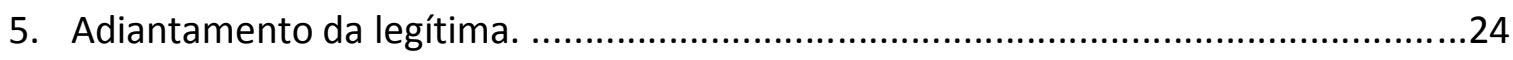

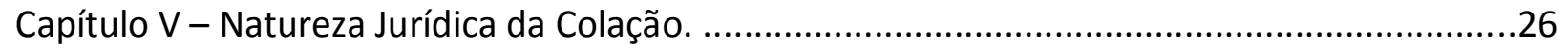

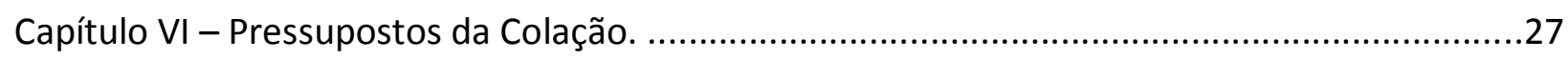

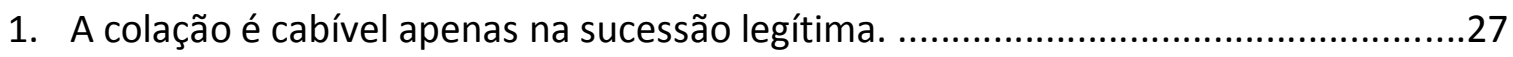

2. Existência de co-herdeiros necessários, descendentes. ............................................27

3. A ocorrência de uma liberalidade feita em vida, pelo ascendente, em favor de descendente ou do cônjuge sobrevivente. ..........................................................28

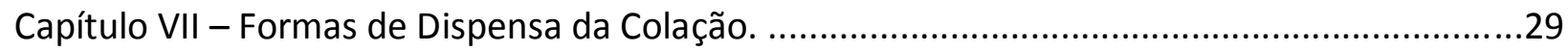

Capítulo VIII - Sujeitos Obrigados à Colação. .......................................................................33

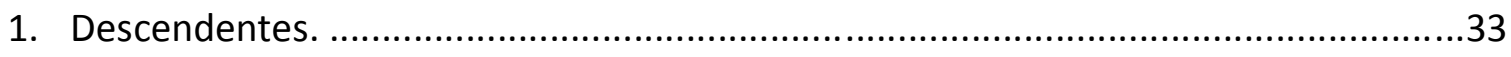

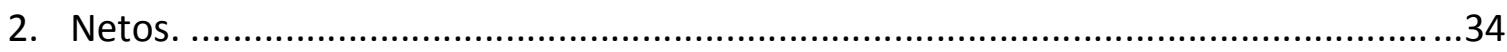

3. Colação das doações realizadas por ambos os cônjuges, em favor de descendente

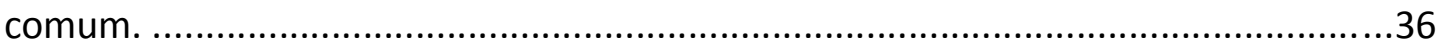

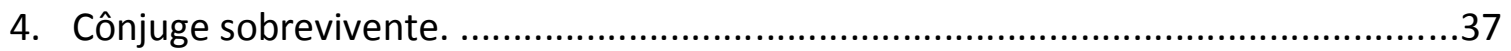

5. Colação pelo renunciante ou pelo excluído da herança. ........................................38

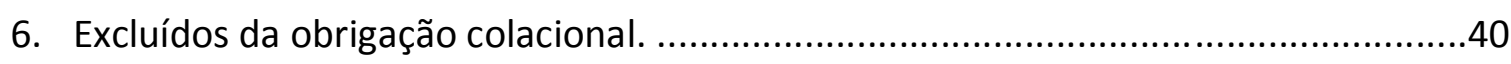


Capítulo IX - Legitimidade Para Pedir a Colação.

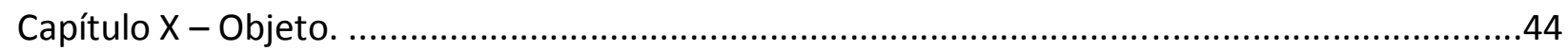

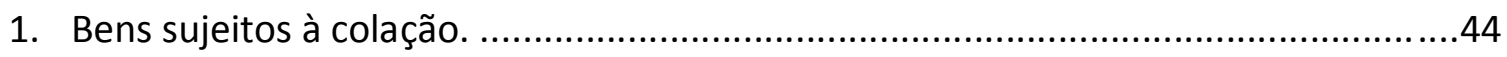

2. Bens e despesas excluídos da conferência colacional. ..............................................46

Capítulo XI - Modos de Realização da Colação. ...........................................................................52

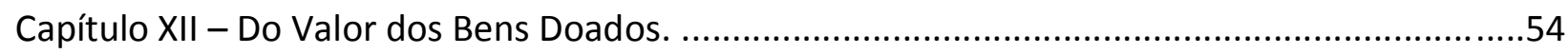

Capítulo XIII - Aspectos Processuais da Colação. ...................................................................58

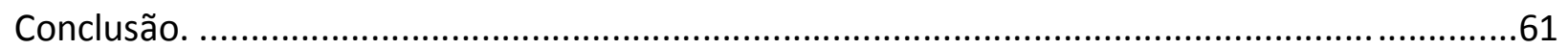

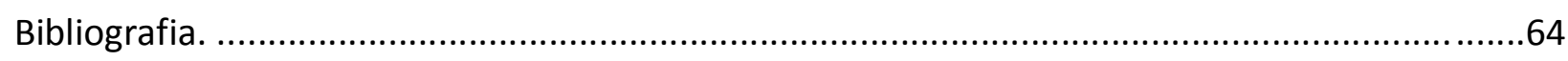


Abreviações.

CC - Código Civil

CPC - Código de Processo Civil

Art - Artigo 


\section{Introdução.}

Como diz Mário Quintana, a morte sempre chega pontualmente na hora incerta. Talvez, seja por este motivo que, dentre os ramos do direito civil, o direito das sucessões seja o mais indesejado.

Certo é que ninguém gosta de falar da morte. Entretanto, não há dúvida que a morte virá e, por isso, faz-se imprescindível estudar as consequências que dela advém.

Diante disto, o presente trabalho tem como escopo analisar profundamente um dos institutos menos conhecidos e estudados sobre o direito sucessório, qual seja, a colação.

Este instituto revela-se deveras importante, pois ele é o instrumento que garante a igualdade das legítimas dos herdeiros necessários, o que, para Caio Mário da Silva Pereira, é o princípio dominante no direito sucessório moderno ${ }^{1}$.

Entretanto, apesar de poucas terem sido as mudanças desde a sua origem na Roma antiga, o instituto foi deixado de lado tanto pelo legislador pátrio, como pelos doutrinadores de um modo geral.

Todos os artigos do Código Civil que tratam sobre o tema são controversos e mal redigidos. E, como se isto não bastasse, em alguns casos, como no da apuração do valor do bem a ser colacionado, o Código de Processo Civil dispõe de maneira contrária à Lei Substantiva Civil.

Os doutrinadores pouco escreveram sobre o tema, apesar da necessidade da análise do instituto, em virtude da péssima redação feita pelo legislador. Por mais incrível que possa

\footnotetext{
${ }^{1}$ Silva Pereira, Caio Mário. Instituições de Direito Civil, Volume VI. 18a Ed. Rio de Janeiro: GEN/Editora Forense, 2010. p. 372.
} 
parecer, provavelmente, quem melhor abordou o tema foi Carlos Maximiliano, em sua obra datada de 1943, quando ainda vigia o Código Civil de $1916^{2}$.

Então, diante da necessidade iminente, propomo-nos a realizar uma análise cuidadosa do instituto da colação, perpassando pelas principais posições doutrinárias, sem deixar de lado, é claro, o posicionamento da jurisprudência acerca de cada tópico da matéria.

\footnotetext{
${ }^{2}$ Maximiliano, Carlos. Direito das Sucessões, volume III. 2a Ed. Rio de Janeiro: Livraria Editora Freitas Bastos, 1943.
} 


\section{Capítulo I - Direito das Sucessões. Breves Considerações.}

O principal objetivo deste capítulo é relembrar alguns tópicos do direito das sucessões, que são imprescindíveis para a compreensão do estudo sobre a colação. Com efeito, doravante serão demonstrados de forma clara e direta tais institutos.

\section{1- Espécies de sucessões.}

O termo sucessão aplica-se a todos os modos derivados de aquisição de domínio. Indica o ato pelo qual alguém sucede a outrem, investindo-se, no todo ou em parte, nos direitos que Ihe pertenciam.

A sucessão, isto é, a transferência de bens de uma pessoa a outra, pode se dar de duas formas: por vontade das partes ou em razão da morte. Se decorrer da manifestação de duas ou mais pessoas, se diz que a sucessão é inter vivos. Quanto aos direitos sucessórios, a transmissão só pode ocorrer em razão da morte, daí causa mortis ${ }^{3}$.

A sucessão causa mortis envolve a transferência de direitos e obrigações de uma pessoa morta a uma pessoa viva. De outro vértice, a inter vivos assume as formas de cessão de crédito, doações e compra e venda.

Na sucessão causa mortis existem algumas modalidades sucessórias que destacaremos, sendo elas, a sucessão legítima e a sucessão testamentária.

Apesar da infelicidade do legislador, tendo em vista que não há sucessão ilegítima, sucessão legítima é aquela que resulta da lei. Esta também é chamada de sucessão $a b$

\footnotetext{
${ }^{3}$ Dias, Maria Berenice. Manual das Sucessões. 2a Ed. São Paulo. Editora Revista dos Tribunais. 2011. p. 99.
} 
intestato, o que significa sucessão sem testamento. Se o falecido, em vida, não manifestou sua vontade, seus bens são transmitidos a quem o legislador indica como herdeiro.

Por sua vez, a sucessão testamentária, como sugere o próprio nome, é a transmissão da herança por meio de testamento. Esta ocorre através da manifestação de vontade do testador, obviamente antes do seu falecimento, indicando quem deseja que fique com seu patrimônio após sua morte.

Antecipamos que a colação só é cabível em caso de sucessão legítima, pois, como se verá adiante, a finalidade deste instituto é igualar a legítima dos herdeiros necessários.

\section{2- Herdeiros necessários. A legítima e a porção disponível.}

Os herdeiros legítimos são os sucessores eleitos pela lei. Estes herdeiros, através da ordem de vocação hereditária (art. 1829, CC), concorrem na herança do de cujus, se estiverem no mesmo grau de preferência, e excluem os demais, se em ordem anterior de preferência. A exceção ao princípio da preferência de classes é a classe dos cônjuges que, em certas circunstâncias, concorrem com os descendentes e em todas as hipóteses com os ascendentes.

Os herdeiros legítimos se subdividem em necessários e facultativos. São necessários os herdeiros com direito a uma parcela mínima de 50\% (cinquenta por cento) do acervo de bens do falecido, da qual não podem ser privados por disposição de última vontade.

Por sua vez, os herdeiros facultativos são aqueles que podem ser privados da herança, bastando ao testador não os contemplar nas disposições de última vontade. Esta categoria abrange apenas os colaterais até o 4 으 grau.

O artigo 1.845, do Código Civil, estabelece quem são os herdeiros necessários e indica a ordem segundo a qual são chamados a recolher a legítima: "são herdeiros necessários os descendentes, os ascendentes e o cônjuge". 
Os herdeiros necessários também são denominados de legitimários ou reservatários.

Os bens do testador são divididos em duas partes, quais sejam, a disponível e a legítima. A parte disponível é a porção da herança, constituída da metade dos bens do testador, ao tempo de sua morte, e sobre a qual ele tem ampla liberdade de disposição.

Por outro lado, a parte da herança que é reservada exclusivamente aos herdeiros necessários, denominada de legítima ou reserva, equivale à metade do acervo dos bens do testador, conforme dispõe o artigo 1.846, do Código Civil: "Pertence aos herdeiros necessários, de pleno direito, a metade dos bens da herança, constituindo a legítima".

O artigo em questão não deixa quaisquer dúvidas que, havendo herdeiros necessários, o testador só poderá dispor da metade da herança, princípio este também constante no artigo 1.789, do Código Civil ${ }^{4}$.

A existência de herdeiros necessários limita a liberdade do testador de dispor dos seus bens. É a legítima que garante esta margem de limitação, pois esta é protegida enquanto o autor da herança vive, por isto, é que não se pode doar livremente a totalidade do patrimônio.

Legítima é, pois, a porção (metade) que a lei reserva aos herdeiros necessários, sobre o acervo existente, quando da abertura da sucessão. E os herdeiros que ela tem direito denominam-se necessários (reservatários ou forçados) em virtude da segurança legal de seus interesses contra o arbítrio do testador ${ }^{5}$.

A porção legítima é calculada sobre o ativo da herança, isto é, a herança líquida, conforme se depreende do artigo 1.847, do Código Civil: “Calcula-se a legítima sobre o valor

\footnotetext{
${ }^{4}$ Código Civil, artigo 1.789: "Havendo herdeiros necessários, o testador só poderá dispor da metade da herança."

${ }^{5}$ Oliveira Leite, Eduardo de. Comentários ao Novo Código Cívil - Do Direito das Sucessões. 5ạ Ed. Rio de janeiro. Editora GEN/Forense. 2009. p. 334.
} 
dos bens existentes na abertura da sucessão, abatidas as dívidas e as despesas do funeral, adicionando-se, em seguida, os bens sujeitos à colação".

Aparentemente, o patrimônio é constituído pela herança - o relictum -, o que foi deixado pelo autor da herança. Mas não é assim. O cálculo da legítima exige operações mais complexas. Na realidade, o artigo 1.847 manda considerar para o cálculo da legítima: 1ㅇ) os bens existentes no patrimônio do autor da sucessão à data da sua morte; $2^{\circ}$ ) o valor dos bens doados (que o autor englobou na noção de colação); 3ํ) as dívidas da herança; 4ㅇ) as despesas do funeral e 5ㅇ) o valor dos bens sujeitos à colação ${ }^{6}$.

Ademais, faz-se imperioso trazer à baila o disposto no artigo 1.849, do Código Civil: "O herdeiro necessário, a quem o testador deixar a sua parte disponível, ou algum legado, não perderá o direito à legítima".

Este artigo não apenas ratifica que aos herdeiros necessários a lei assegura a quota legítima, mas, também, afirma que nada impede que o testador deixe sua porção disponível ao herdeiro necessário. Isto se deve, pois, conforme dito anteriormente, o testador dispõe da sua quota disponível como bem entender. Enquanto a quota não ultrapassar a metade disponível, a disposição é plenamente válida, não precisando ser colacionada no inventário, ao contrário das doações que se adicionam ao valor dos bens deixados, para o cálculo da legítima.

\section{3- Doações inoficiosas.}

Havendo herdeiros necessários o testador só pode doar a metade de seus bens. Este mandamento legal é válido tanto nos casos de doações feitas a terceiros, como as feitas em favor de herdeiros necessários.

\footnotetext{
${ }^{6}$ Oliveira Leite, Eduardo de. Comentários ao Novo Código Civil - Do Direito das Sucessões. 5a Ed. Rio de janeiro. Editora GEN/Forense. 2009. p. 337.
} 
Se este teto legal não for respeitado, a doação é nula, conforme o disposto no artigo 549, do Código Civil: "Nula é também a doação quanto à parte que exceder à de que o doador, no momento da liberalidade, poderia dispor em testamento."

A inoficiosidade se afere no momento da doação, com base no patrimônio existente naquela data, como se o doador falecesse nesse mesmo dia. Um acréscimo patrimonial posterior não afasta o caráter inoficioso da liberalidade, assim como a posterior ruína do doador não torna inoficiosas liberalidades pretéritas ${ }^{7}$.

Destarte, são consideradas doações inoficiosas aquelas cujo valor, no momento da liberalidade, ultrapassa a metade disponível do doador, violando, então, a legítima.

A solução para corrigir possíveis violações à legítima é a redução da doação até o limite da parte disponível, conforme estabelece o artigo 1.967, do Código Civil $^{8}$.

\footnotetext{
${ }^{7}$ Dias, Maria Berenice. Manual das Sucessões. 2a Ed. São Paulo. Editora Revista dos Tribunais. 2011. p. 593.

${ }^{8}$ Código Civil, artigo 1.967: “Art. 1.967. As disposições que excederem a parte disponível reduzir-se-ão aos limites dela, de conformidade com o disposto nos parágrafos seguintes. $\S 1^{\circ} \mathrm{Em}$ se verificando excederem as disposições testamentárias a porção disponível, serão proporcionalmente reduzidas as quotas do herdeiro ou herdeiros instituídos, até onde baste, e, não bastando, também os legados, na proporção do seu valor. $\S 2^{\circ}$ Se o testador, prevenindo o caso, dispuser que se inteirem, de preferência, certos herdeiros e legatários, a redução far-se-á nos outros quinhões ou legados, observando-se a seu respeito a ordem estabelecida no parágrafo antecedente."
} 


\title{
Capítulo II. Colação. Conceito.
}

Colação é o ato pelo qual os herdeiros descendentes de mesma classe, que concorrem à sucessão do ascendente comum, reúnem ao monte partível quaisquer liberalidades que dele em vida receberam, sob pena de sonegados, para que sejam conferidas e igualadas as respectivas legítimas (CC, arts. 2.002 e 2.003).

No direito sucessório brasileiro, o princípio norteador é o da igualdade das legítimas. A colação tem como finalidade justamente igualar as partes legítimas que, em determinado momento, se tornaram desiguais por força de doação feita pelo ascendente a descendente ${ }^{9}$.

Carlos Maximiliano, com a clareza costumeira, ensina, verbis:

\begin{abstract}
"Consideram-se, em regra, as doações, os dotes e quaesquer outras liberalidades a descendentes, como adeantamento de legítima; presume-se ter sido este o intuito do ascendente - não romper com a igualdade entre a prole; antecipar o gozo, porém não o domínio definitivo de certos bens; permitir que o filho desfrute imediatamente o que só iria à sua posse quando se abrísse a sucessão paterna, sem prejuízo algum para os irmãos, cujos quinhões seriam eqüipolentes ao do beneficiado. Por isso, verificado o obito, a massa hereditaria é acrescida dos bens entregues à prole em vida do progenitor; entram no inventario como se ainda fizessem parte do patrimonio do doador, e sofrem a redução da parcela que prejudica a legitima dos outros sucessores forçados. Fica o acervo como se não tivesse ocorrido a dádiva ${ }^{10 \prime \prime}$ (ortografia em conformidade com à época).
\end{abstract}

\footnotetext{
${ }^{9}$ Civil. Sucessão. Inventário e partilha. Ação de sonegados. Bem doado a herdeiro necessário. Ausência de colação. Finalidade de instituto - igualação das legítimas. Alteração da parte indisponível do autor da herança. llegitimidade ativa do herdeiro testamentário. Recurso parcialmente provido. 1. Não há falar em negativa de prestação jurisdicional nos embargos de declaração, se o Tribunal de origem enfrenta a matéria posta em debate na medida necessária para o deslinde da controvérsia, ainda que sucintamente. A motivação contrária ao interesse da parte não se traduz em maltrato ao art. 535 do CPC. 2. A finalidade da colação é a de igualar as legítimas, sendo obrigatório para os descendentes sucessivos (herdeiros necessários) trazer à conferência bem objeto de doação ou de dote que receberam em vida do ascendente comum, porquanto, nessas hipóteses, há a presunção de adiantamento da herança (arts. 1.785 e 1.786 do CC/1916; arts. 2.002 e 2.003 do CC/2002). 3.0 instituto da colação diz respeito, tão somente, à sucessão legítima; assim, os bens eventualmente conferidos não aumentam a metade disponível do autor da herança, de sorte que benefício algum traz ao herdeiro testamentário a reivindicação de bem não colacionado no inventário. 4. Destarte, o herdeiro testamentário não tem legitimidade ativa para exigir à colação bem sonegado por herdeiro necessário (descendente sucessivo) em processo de inventário e partilha. 5. Recurso especial parcialmente provido. (STJ, Resp 400948/SE, Ministro relator: Vasco Della Giustina, Terceira Turma, julgamento em 23/03/2010, grifamos).

${ }^{10}$ Maximiliano, Carlos. Direito das Sucessões, volume III. 2a Ed. Rio de Janeiro: Livraria Editora Freitas Bastos, 1943. p. 423.
} 
Salvo expressa declaração, presume-se que quando um ascendente faz uma doação a um descendente ele antecipa a legítima que este já teria direito (CC, art. 544) ${ }^{11}$. Em outras palavras, o descendente recebe antecipadamente a parte da legítima que só receberia quando aberta a sucessão do seu ascendente.

O herdeiro beneficiado que se omite a conferir os bens, quando aberta a sucessão do ascendente doador, é considerando sonegador. A pena imposta aos sonegados é a perda da liberalidade recebida pelo ascendente doador quando este ainda era vivo (CC, art. 1.992) ${ }^{12}$.

Doações feitas a qualquer pessoa saem da parte disponível do patrimônio do doador, isto é, daquilo que ele pode dispor em testamento (CC, art. 549). De outro vértice, as doações feitas em beneficio de herdeiros necessários recaem sobre a parte indisponível do patrimônio do doador, por isto são consideradas adiantamento de legítima (CC, art. 544). A doação a herdeiro necessário só irá ser computada da parte disponível se assim declarar expressamente o ascendente doador, fato este que dispensará o herdeiro necessário de trazer à colação as liberalidades recebidas (CC, art. 2.006).

Faz-se necessário, então, distinguir colação de redução das liberalidades. A primeira, conforme já visto, tem o fito de igualar as partes legítimas dos herdeiros necessários. Neste caso a doação é válida, pois foi retirada da meação disponível do doador. De outro vértice, a redução tem a finalidade de fazer com que as liberalidades se contenham dentro daquela metade, quer beneficie algum herdeiro, quer favoreça um estranho. A colação assenta teoricamente na vontade presumida do morto, ao passo que a redução é de ordem pública. Em

\footnotetext{
${ }^{11}$ Código Civil, artigo 544: “A doação de ascendentes a descendentes, ou de um cônjuge a outro, importa adiantamento do que lhes cabe por herança".

${ }^{12}$ Código Civil, artigo 1.992: “O herdeiro que sonegar bens da herança, não os descrevendo no inventário quando estejam em seu poder, ou, com o seu conhecimento, no de outrem, ou que os omitir na colação, a que os deva levar, ou que deixar de restituí-los, perderá o direito que sobre eles lhe cabia."
} 
consequência, é válida a dispensa de colação, a que adiante aludiremos, mas não pode o falecido dispensar a redução ${ }^{13}$.

Não há qualquer distinção. Quer a doação feita a herdeiros necessários, quer a feita a terceiros, precisa obedecer ao teto legal. Quando ultrapassado este limite, a doação é nula (CC, art. 549). O cônjuge que receber bens a títulos de doação que ultrapassem o limite da parte disponível também se sujeita à redução por inoficiosidade quando concorrer com descendentes e ascendentes. O desrespeito à legítima, conforme foi visto no primeiro capítulo, chama-se doação inoficiosa e gera a nulidade da doação. Os herdeiros podem impugnar a doação mesmo enquanto o doador estiver vivo ${ }^{14}{ }^{15}$.

Em decisão histórica o Supremo Tribunal Federal traçou seu posicionamento acerca da diferença entre a colação e a redução das liberalidades:

\begin{abstract}
"Redução das liberalidades. Colação - A colação é o ato pelo qual o co-herdeiro descendente reúne ao monte partível as doações ou os dotes, que recebeu do de cujus (Cód. Civil, art. 1.785). Diz respeito, portanto, às doações ou dotes por inteiro e não à metade do seu valor. Quando há dispensa de colação, é que se tem de atender a metade disponível, pois aquela dispensa não poderá exceder essa metade (art. 1.788). Dá-se, então, havendo excesso, a redução, que não há de se confundir com colação. Se pela colação não se incorporasse tudo ao monte-partível, não se verificaria a igualdade patrimonial colimada e seria inútil o instituto da dispensa de colação" (STF - AGI 16627, 24/04/1954, Ministro Relator Luís Gallotti).
\end{abstract}

\footnotetext{
${ }^{13}$ Silva Pereira, Caio Mário. Instituições de Direito Civil, Volume VI. 18a Ed. Rio de Janeiro: GEN/Editora Forense, 2010. p. $372 / 373$.

${ }^{14}$ Dias, Maria Berenice. Manual das Sucessões. 2ª Ed. São Paulo. Editora Revista dos Tribunais. 2011. p. 592.

15 “Anulação de doação. Requerente reconhecida em ação de reconhecimento de paternidade. Artigo 1176 do Código Civil. Doação inoficiosa. Nulidade da doação na parte que exceder a parte disponivel. É possível o ajuizamento, pois não se está requerendo a herança para si. Sentença reformada. Recurso provido em parte". (TJSP, AC 994.09.300621-8, rel. Des. Beretta da Silveira, 3ạ Câm. Dir. Priv., j. 09.03.2010)
} 


\section{Capítulo III - Histórico da Colação.}

Colação (rapport, dos franceses. Collazione, dos italianos; colación, dos espanhóis; ausgleichung, dos alemães) é o ato de reunir ao monte partível qualquer liberalidade recebida do de cujus, pelo herdeiro descendente, antes da abertura da sucessão. O vocábulo teve origem em Roma. Provém do termo latino - collatio, oriundo por sua vez do supino - collatum, do verbo conferre, o qual significa, em português, conferir, ajuntar, reunir, trazer juntamente.

Este é o motivo pelo qual se empregam de modo equivalente as expressões trazer à colação e conferir. Para o direito sucessório não há diferença entre colação e conferência.

O instituto em apreço, desde a sua origem, na antiga Roma, sempre teve a mesma finalidade, qual seja, estabelecer a igualdade entre os sucessores. No direito patriarcal na Roma antiga, o filho emancipado tornava-se paterfamilias, desligando-se completamente da sua família de origem. Assim sendo, este perdia os eventuais direitos que tinha sobre os bens de seus ascendentes, inclusive os direitos oriundos da sucessão causa mortis.

A partir do direito pretoriano houve uma evolução no direito civil, o qual passou a chamar tanto os filhos in potestate patria quanto os filhos emancipados, conjuntamente, à bonorum possessio ab intestato e à bonorum possessio contra tabulas.

Os filhos emancipados, desde cedo, iniciavam a formação de patrimonio próprio, eles trabalhavam para si próprios. De outro vértice, os demais filhos que não eram emancipados (os sui) trabalhavam em comum, para aumentar a fortuna do pai.

Diante disto, quando falecia o pai, apresentava-se uma enorme injustiça, pois, o filho emancipado, que lucrou com a liberdade, absorvendo todo fruto de seu trabalho para si, iria participar da divisão dos bens do pai, que eram frutos das atividades dos irmãos que se encontravam sob o pátrio poder. 
Com a finalidade de cessar esta situação de injustiça, o pretor, através de edito, determinou que o filho emancipado devesse conferir todos os bens que tivesse adquirido desde a sua emancipação até a morte do pater, sempre que concorresse à herança com outros herdeiros não emancipados. Surge, então, a collatio bonorum vel emancipati.

Posteriormente, o dever de colação foi estendido à filha, no que se refere ao dote havido do pater; era a chamada collatio dotis. A filha casada que se encontrava sujeita ao pátrio poder do falecido pai, e não do marido, recebia um dote, que se tornava propriedade deste. Com a dissolução do casamento, a mulher, em certas condições, podia exigir do ex-marido a restituição do dote. Sendo ela casada sine manu, podia concorrer à sucessão do pai.

Mais tarde, através do advento de uma lei do Imperador Leão, promulgada em 472, foi abolida a colação dos bens dos emancipados, sendo substituída pelo dever de colacionar todas as liberalidades feitas em vida pelos pais a qualquer filho, quer fosse emancipado ou não - era a collatio descendentium (colação dos descendentes).

Desta forma, os filhos de ambos os sexos, emancipados ou não, eram obrigados a conferir o dote ou doação ante nuptias que tivessem recebido, e bem assim as filhas e os filhos emancipados quanto aos bens adquiridos de seus ascendentes ao tempo da emancipação ou depois dela.

Doravante, por meio da Novela 18, Justiniano estendeu o dever de conferir até a sucessão testamentária, excetuando, porém, o filho a quem o pater explicitamente liberasse daquele encargo.

Assim sendo, com a extinção da collatio emancipati, foi estabelecida a igualdade entre os filhos emancipados e os que viviam sob o pátrio poder.

O instituto da colação, de origem romana, conforme visto, passou ao direito vigótico, deste passou ao direito francês, e, através do direito português, passou ao direito pátrio. 
Conforme será analisado doravante nesta obra, a lei brasileira não impõe o dever de conferência a todos os herdeiros necessários, mas, apenas, aos descendentes em linha reta e o cônjuge ou companheiro sobrevivente. 


\section{Capítulo IV. Fundamentos.}

Com a finalidade de justificar a exigência da colação, a doutrina elenca diversos fundamentos. Desde o início, deixamos claro que de todas as teorias expostas abaixo, as que melhor servem ao direito pátrio são a da igualdade entre os descendentes e a da antecipação da herança.

\section{Vontade presumida do ascendente.}

O Primeiro fundamento que a doutrina utiliza para justificar a exigência da colação é a vontade presumida de que o ascendente tratava de igual afeto todos seus descendentes. Por esta razão, deve-se manter igualadas as partes legítimas dos herdeiros necessários ${ }^{16}{ }_{-}^{17}$.

O ascendente permite que o seu herdeiro necessário desfrute do bem que só receberia quando abrisse a sucessão paterna. Isto é, há a antecipação do gozo, mas jamais o domínio do bem em favor do herdeiro beneficiado. Por este motivo, faz-se imperativo que o herdeiro donatário colacione o bem quando abrir a sucessão do ascendente doador.

Apesar de ser invocado por ilustres doutrinadores, o fundamento da vontade presumida do ascendente vem sofrendo fortes críticas. Orlando Gomes sacramenta que "a teoria da vontade presumida deve ser rejeitada, não somente por se atritar com a disciplina legal do instituto, como, também, por defeito técnico. Choca-se, realmente, com a norma que faculta ao ascendente dispensar a colação. Tecnicamente, as regras que estabelecem presunção não criam, como na hipótese, direitos substantivos nem constituem obrigações, limitando-se a

\footnotetext{
${ }^{16}$ Nesse sentido: Maximiliano, Carlos. Direito das Sucessões, volume III. 2a Ed. Rio de Janeiro: Livraria Editora Freitas Bastos, 1943. p. 423.

${ }^{17}$ Nesse sentido: “Conforme aponta Cunha Gonçalves, a opinião dominante entende que a colação é baseada na vontade presumida do de cujus, que, desejando estabelecer a igualdade entre os herdeiros, supõe que o donatário recebe a coisa doada a título de antecipação de herança e sob condição de a trazer ao monte partível, ou descontá-la do seu quinhão, ao abrisse a sucessão, pois é justo presumir que o autor da herança dedicava a todos os seus descendentes igual afeto, não havendo razão para distinguir entre uns e outros, se não fez expressa menção". Rodrigues, Sílvio. Direito Civil, Direito das Sucessões, Volume 7. 26ạ Ed. Saraiva, 2003. p. 308.
} 
impor ao juiz o dever de considerar provado determinado fato jurídico. Da vontade presumida do ascendente não poderia nascer a obrigação de conferir, constituída por lei supletiva ${ }^{18}{ }_{-}^{19 "}$.

Em que pese o respeito que se nutre pelos defensores da teoria da vontade presumida do ascendente, assim como Orlando Gomes, acredito que este fundamento já foi superado. Seria utópico acreditar que todas as famílias são perfeitas e que todos os pais possuem a mesma afinidade com todos os filhos. Se assim fosse, o legislador não teria dado a faculdade ao ascendente doador de liberar o herdeiro beneficiado do encargo da colação.

Diante disto, também acredito que tal fundamento deve ser rechaçado, pois vai de encontro com o próprio instituto da colação que possibilita ao ascendente dispensar da colação o herdeiro beneficiado (CC, arts. 2005 e 2006) ${ }^{20}$.

\section{A compropriedade familiar.}

O segundo fundamento apresentado pela doutrina minoritária para justificar a exigência de colação é a compropriedade familiar.

Para os defensores deste fundamento, os descendentes teriam a compropriedade dos bens que o ascendente possuía em vida. Sendo assim, se um dos descendentes fosse agraciado por uma doação feita em vida pelo ascendente, ele deveria colacionar o bem recebido, pois, na verdade, este bem é de compropriedade de todos os ascendentes.

\footnotetext{
${ }^{18}$ Gomes, Orlando. Sucessões. Rio de Janeiro. 14a Ed. Editora Forense, 2008. p. 288.

${ }^{19}$ Nesse sentido: "Parece haver um equívoco naqueles que colocam a natureza da colação na vontade presumida do falecido, a fim de manter a igualdade de tratamento para com os descendentes, e mesmo com o cônjuge em relação a eles. Ora, fosse assim, contemplaria, em vida, todos os descendentes e o cônjuge. Se apenas um ou mais descendentes são favorecidos, é porque pretendeu o titular dos bens favorecê-los em relação aos outros" Rizzardo, Arnaldo. Direito das Sucessões. 6a Ed. Rio de janeiro. Editora GEN/Forense. 2011. p. 643.

${ }^{20}$ Nesse sentido: “No dizer de Zeno Veloso, a dispensa de colação feita pelo doador destrói a presunção de que este queria fazer, simplesmente, uma antecipação de herança ao donatário, pois fica claro e inequívoco, com tal liberalidade que o doador quer gratificar melhor e beneficiar mais o aludido herfeiro, destinando a este maior proporção que aos outros". Venosa, Sílvio de Salvo. Direito Civil, Direito das Sucessões volume 7. São Paulo. 4a Ed. Editora Atlas, 2004. p. 377.
} 
Com o devido respeito, discordamos desta teoria. É cediço que os herdeiros necessários, enquanto viver o ascendente, possuem uma expectativa de direito de receber a herança deste. De forma alguma, podemos afirmar que esta expectativa de direito converte-se em compropriedade $^{21}$. O patrimônio do ascendente é dele enquanto viver, e cabe ao mesmo a liberdade de sobre ele dispor, é claro, respeitando as limitações impostas pelos artigos 548 e 549 do Código Civil, verbis:

Artigo 548: É nula a doação de todos os bens sem reserva da parte, ou renda suficiente para a subsistência do doador.

Artigo 549: Nula é também a doação quanto à parte que exceder à de que o doador, no momento da liberalidade, poderia dispor em testamento.

\section{Interesse superior da família.}

Inaceitável, também, fundamentar a obrigatoriedade de colação sob o argumento do interesse superior da família. Este fundamento é deveras genérico, abstrato, não serve de alicerce para sustentar a necessidade de conferir doações feitas pelo ascendente em favor de herdeiro necessário.

\section{A igualdade entre os descendentes.}

Ao contrário dos três fundamentos supracitados, a teoria da igualdade entre descendentes ou igualdade entre legítimas foi um dos nortes que inspiraram o legislador na regulamentação do instituto da colação ${ }^{22}$.

\footnotetext{
${ }^{21}$ Nesse sentido: "Inaceitável, igualmente, a teoria da compropriedade familiar, por se apoiar em uma ficção. Durante a vida do ascendente, tem os descendentes apenas mera expectativa a igual participação no patrimônio de que é exclusivo titular o ascendente com liberdade de dispor, ainda limitada". Gomes, Orlando. Sucessões. Rio de Janeiro. 14aㅡ Ed. Editora Forense, 2008. p. 288.

22 “Inventário. Colação. Sua finalidade é igualar a legítima dos herdeiros (art. 1785 do Código Civil). Na espécie, é incontroverso que os doadores cuidaram de igualar as partes de todos, a feição doação-partilha, com a presença e expresso assentimento dos donatários, maiores e capazes. Ao lado disso, é de se considerar que a eventual mutação dos valores não tem o condão de alterar a igualdade das legítimas. 0 acórdão recorrido, ao admitir o instituto da colação, negou vigência ao disposto no art. 1.785 do Código Civil, bem assim discrepou da melhor
} 
O eminente professor Carlos Roberto Gonçalves afirma que a doutrina contemporânea sustenta que desde a sua origem, no direito romano, a colação assenta o seu fundamento jurídico no princípio da equidade das legítimas ${ }^{23}{ }_{-} 24$.

Os descendentes e o cônjuge sobrevivente são herdeiros necessários do de cujus, nesta qualidade, possuem, de direito, e em frações iguais, a metade dos bens deste. Quando um ascendente beneficia, em vida, um descendente ou o cônjuge sobrevivente com uma doação ou qualquer outra liberalidade, está quebrando com aquela condição de igualdade e desfalcando o monte em detrimento dos demais ${ }^{25}$.

interpretação jurisprudencial. Provimento do primeiro recurso, para restabelecer a sentença, julgando-se prejudicado o segundo" (STF, RE 90812, Ministro Relator Djaci Falcão, julgamento em 16/12/1980).

${ }^{23}$ Gonçalves, Carlos Roberto. Direito Civil Brasileiro, volume 7. São Paulo. 5a Ed. Editora Saraiva, 2011. p. 538/539.

${ }^{24}$ Nesse sentido: "A colação foi introduzida pelo pretor, quando permitiu aos filhos emancipados participarem da sucessão de seus pais. Enquanto os filhos que continuavam sobre a patria potestas não tinham patrimônio, pois tudo que adquiriam incorporava-se ao patrimônio paterno, os filhos emancipados, em virtude da sua condição sui juris, eram titulares de um patrimônio próprio. Ora, era injusto, por desigual, permitir aos emancipados concorrerem em igualdade de condições, na herança paterna, com os seus outros irmãos; por essa razão, o pretor obrigou-os a conferir, naquela sucessão, os bens que tinham adquirido por si próprios, após sua emancipação, e que teriam incorporado ao patrimônio paterno, não fosse a emancipação. Com o tempo, e à medida que se permitiu também aos filhos sob o pátrio poder terem um patrimônio, a colação mudou de objeto, pois, por seu intermédio, impôs-se a todos os filhos o dever de conferirem, na sucessão paterna, os bens recebidos em vida. Em qualquer dos casos é fácil observar que o escopo foi sempre o mesmo, isto é, propiciar a maior igualdade entre os sucessores" Venosa, Sílvio Salvo. Direito Civil, Direito das Sucessões, volume 7. São Paulo. 26a Ed. Editora Saraiva, 2003. p.308/309.

${ }^{25}$ Nesse sentido: "A teoria da igualdade entre descendentes inspirou o legislador pátrio na regulamentação do instituto. Os descendentes são herdeiros obrigatórios. Pertence-lhes, de pleno direito, a metade dos bens do ascendente. Esta parte da herança tem de ser dividida em frações iguais. Quando o ascendente contempla, em vida, um deles, revogaria o princípio da igualdade das legitimas se o bem doado não tivesse de ser conferido para a constituição da metade indispensável. Os demais herdeiros seriam prejudicados, porque, além do que receberá gratuitamente antes da abertura da sucessão, o favorecido herdaria igual quota". Gomes, Orlando. Sucessões. Rio de Janeiro. 14a Ed. Editora Forense, 2008. p. 289. 
Desta forma, a colação tem o fito de restabelecer a condição de igualdade entre os herdeiros necessários, pois obriga aquele herdeiro beneficiado a reunir ao monte partível quaisquer liberalidades recebidas, em vida, pelo de cujus $^{26}$.

\section{Adiantamento de legítima.}

A forma de impor obediência ao princípio da igualdade entre os descendentes é considerando as liberalidades feitas pelo ascendente doador, em vida, beneficiando herdeiro necessário, como adiantamento de legítima (CC, art. 544).

Neste sentido afirma Arnaldo Rizzardo: "Todo ato de liberalidade, inclusive doação, feito a descendente e/ou herdeiro necessário nada mais é que adiantamento de legítima, impondo, portanto, o dever de trazer à colação, sendo irrelevante a condição dos demais herdeiros. ${ }^{27}{ }^{28 \prime \prime}$

Pode-se afirmar, portanto, que a doutrina contemporânea considera ter a colação como escopo a equidade e a igualdade das legítimas, fundando-se na vontade presumida do finado. Comprova-se a veracidade dessa concepção o fato de o doador necessitar, se desejar realmente gratificar o donatário, colocando-o em posição vantajosa em relação aos demais descendentes, declarar expressamente essa intenção, dispensando da colação o beneficiário,

\footnotetext{
${ }^{26}$ Nesse sentido: Dias, Maria Berenice. Manual das Sucessões. 2a Ed. São Paulo. Editora Revista dos Tribunais. 2011. p. 591.

${ }^{27}$ Rizzardo, Arnaldo. Direito das Sucessões. 6a Ed. Rio de janeiro. Editora GEN/Forense. 2011. p. 642.

${ }^{28}$ Recurso especial. Sucessões. Inventário. Partilha em vida. Negócio formal. Doação. Adiantamento de legítima. Dever de colação. Irrelevância da condição dos herdeiros. Dispensa. Expressa manifestação do doador. - Todo ato de liberalidade, inclusive doação, feito a descendente e/ou herdeiro necessário nada mais é que adiantamento de legítima, impondo, portanto, o dever de trazer à colação, sendo irrelevante a condição dos demais herdeiros: se supervenientes ao ato de liberalidade, se irmãos germanos ou unilaterais. É necessária a expressa aceitação de todos os herdeiros e a consideração de quinhão de herdeira necessária, de modo que a inexistência da formalidade que o negócio jurídico exige não o caracteriza como partilha em vida. - A dispensa do dever de colação só se opera por expressa e formal manifestação do doador, determinando que a doação ou ato de liberalidade recaia sobre a parcela disponível de seu patrimônio. Recurso especial não conhecido. (STJ, Resp 730483/MG, Ministra relatora: Nancy Andrighi, Terceira Turma, julgamento em 03/05/2005).
} 
como prevê o art. 2.005, caput, do Código Civil $^{29}{ }_{-}^{30}$. Neste caso, a doação que antes seria destacada da parte legítima passa a ser destacada da parte disponível.

\footnotetext{
${ }^{29}$ Gonçalves, Carlos Roberto. Direito Civil Brasileiro, volume 7. São Paulo. 5a Ed. Editora Saraiva, 2011. p. 539.

30“Inventário. Colação de bens doados. Dispensa. Adiantamento da legítima. Presunção. Princípio da igualdade da partilha. Agravo de instrumento - Sucessões - Inventário - Decisão agravada que dispensou da colação bens recebidos por doação - ARTS. 1.171 C/C1.785 e seguintes do Código Civil de 1916 - Inexistência de dispensa de colação na escritura pública de doação para a agravada bem como no testamento dos inventariados - Presunção de antecipação de herança - Princípio da igualdade dos quinhões - Decisão que se reforma. 1. Agravo de instrumento contra decisão que dispensou bens recebidos por doação da colação em ação de inventário. 2. "A doação dos pais aos filhos importa adiantamento da legítima." (art. 1.171, CC/1916). 3. Arts. 1.785 e seguintes do Código Civil de 1916. In casu, não houve dispensa de colação na escritura pública de doação para a agravada, bem como nos testamentos dos inventariados. 4. Hipótese na qual não resta comprovada a antecipação equânime das legítimas para os 3 filhos dos inventariados. Doações e celebração de negócios jurídicos diversos em épocas diferenciadas. Impossibilidade de se afirmar com segurança a igualdade entre os valores recebidos pelos herdeiros. 5. Necessidade de se assegurar a igualdade entre os quinhões. PROVIMENTO AO RECURSO." (TJRJ, Ag 0032103-75.2011.8.19.0000, rel. Marcelo Lima Buhatem, 4a Câmara Cível, julgamento em 24/08/2011).
} 


\section{Capítulo V. Natureza Jurídica da Colação.}

Primeiramente, cumpre salientar que não é pacífico o entendimento doutrinário acerca da natureza jurídica da colação.

Parte da doutrina entende que a natureza jurídica da colação funda-se na vontade presumida do ascendente doador. Conforme dito anteriormente, este trabalho não concorda com esta teoria, tendo em vista que este pensamento vai de encontro ao próprio instituto da colação e, além disto, é utópico acreditar que os ascendentes não tem predileções por um ou outro descendente.

Prevalece entre os doutrinadores a opinião de que a natureza jurídica da colação fundase na obrigação imposta legalmente ao herdeiro necessário de restituir ao monte-partível as liberalidades que recebeu do ascendente doador quando este ainda era vivo. Diante disto, chega-se ao objetivo principal deste instituto, qual seja, a igualdade das legítimas dos descendentes, segundo preceitua o artigo 2.003, do Código Civil ${ }^{31}$ :

"A colação tem por fim igualar, na proporção estabelecida neste Código, a legítima dos descendentes e do cônjuge sobrevivente, obrigando também os donatários que, ao tempo do falecimento do doador, já não possuírem os bens doados".

A colação consiste na reconstituição do acervo hereditário para a determinação exata da legítima de cada co-herdeiro descendente, que deve se realizar por força de lei, cumpra ou não o donatário a obrigação de conferir, permanecendo eficaz a doação. É o meio de emendar a ofensa à igualdade.

Sendo simples reconstituição para fim específico, conserva o donatário a propriedade exclusiva do bem doado, superpondo-lhe a sua posição de donatário a de herdeiro, que se torna preeminente.

\footnotetext{
${ }^{31}$ Nesse sentido: Rizzardo, Arnaldo. Direito das Sucessões. 6a Ed. Rio de janeiro. Editora GEN/Forense. 2011. p. 643. e Gomes, Orlando. Sucessões. Rio de Janeiro. 14a Ed. Editora Forense, 2008. p. 289.
} 


\section{Capítulo VI. Pressupostos da Colação.}

No direito brasileiro a colação possui três pressupostos. (i) A colação é cabível apenas na sucessão legítima; (ii) Existência de co-herdeiros necessários, descendentes; (iii) A ocorrência de uma liberalidade feita em vida, pelo ascendente, em favor de descendente ou do cônjuge sobrevivente.

\section{A colação é cabível apenas na sucessão legítima.}

Como primeiro pressuposto podemos citar que a colação cabe apenas nos casos de sucessão legítima. Não há colação na sucessão testamentária porque, como o objetivo da colação é igualar a legítima dos descendentes e estando esta fora do poder de disposição do testador, é na sucessão legítima que se há de colacionar ou conferir a liberalidade dos ascendentes $^{32}$. Havendo apenas herdeiros testamentários, ou legados, ninguém poderá reclamar que se considere, para o monte da parte disponível, aquilo que foi objeto de doação ${ }^{33}$.

\section{Existência de co-herdeiros necessários, descendentes.}

Além disto, para que seja obrigatória a colação, é necessária a existência de coherdeiros necessários, descendentes. Se houver apenas um descendente, não se pode falar em colação, já que não há que se estabelecer qualquer igualdade. Também não há colação quando os legitimários são apenas ascendentes.

\footnotetext{
${ }^{32}$ Oliveira Leite, Eduardo de. Comentários ao Novo Código Cívil - Do Direito das Sucessões. 5a Ed. Rio de janeiro. Editora GEN/Forense. 2009. p. 911.

${ }^{33}$ Nesse sentido: Rizzardo, Arnaldo. Direito das Sucessões. 6ạ Ed. Rio de janeiro. Editora GEN/Forense. 2011. p. 644.
} 
3. A ocorrência de uma liberalidade feita em vida, pelo ascendente, em favor de descendente ou do cônjuge sobrevivente.

Por fim, tem-se como último pressuposto da colação, a ocorrência de uma liberalidade feita em vida, pelo ascendente, em favor de descendente ou do cônjuge sobrevivente. As liberalidades ou doações devem ser entendidas em sentido amplo, de forma que abranja todas as liberalidades com que o de cujus tenha, direta ou indiretamente, gratificado o herdeiro. Assim, as quantias com que o pai solveu, gratuitamente, as dívidas do filho devem ser computadas também na sua legítima. 


\section{Capítulo VII - Formas de Dispensa da Colação.}

A regra geral é que todas as liberalidades ao descendente, feitas em vida pelo inventariado, sejam levadas à colação. Entretanto, não é absoluta a presunção de que todas estas doações possuem o caráter de adiantamento de legítima.

O dever de levar à conferência as doações não é considerado uma questão de ordem pública, mas, sim, de caráter dispositivo. A regra geral da colação conduz o que deve ser feito quando o ascendente falecido é silente sobre o assunto. Isto é, se nada dispôs o falecido, a regra válida é que todas as doações feitas por este, em favor de descendente ou do cônjuge sobrevivente, devem ser levadas à colação ${ }^{34}$.

O artigo 2.005, do Código Civil, dispõe o seguinte:

São dispensadas da colação as doações que o doador determinar que saiam da parte disponível, contanto que não a excedam, computado o seu valor ao tempo da doação. Parágrafo único. Presume-se imputada na parte disponível a liberalidade feita a descendente que, ao tempo do ato, não seria chamado à sucessão na qualidade de herdeiro necessário.

Diante da simples análise do dispositivo em questão, conclui-se que são dispensadas da colação as doações que o doador determinar que saiam da parte disponível, contanto que não a excedam, computando-se este valor ao tempo da doação. Além disso, por força do parágrafo único, do artigo supracitado, ampliou-se a incidência de dispensa de colação à liberalidade feita

\footnotetext{
${ }^{34}$ Nesse Sentido: "A regra geral é ser a liberalidade ao descendente, feita em vida do inventariado, simples antecipação de legítima. A presunção, porém, de assim ter querido o de cujus não é juris et de jure, irrefragável, absoluta; a lei, sobre este particular, não se considera de ordem pública; atribue-se-lhe o caráter dispositivo; ela esclarece o que deve fazer, na falta de determinação do falecido sobre o assunto. Se este se limitou a dar, encorpora-se ao monte-mór o bem e partilha-se o todo resultante da soma. Pode o ascendente determinar, porém, que a dádiva seja considerada parte, não da reserva, mas da quota disponível, neste caso, só se deduz o que excede a soma da quota mencionada com a legítima individual do beneficiado. A liberalidade assim dispensada de vir à colação, é considerada fora da herança, nos limites da disponibilidade; verificado caber na fração de patrimônio que o defunto podia distribuir livremente por um ato entre vivos ou causa mortis, o bem havido pelo filho deixa de ser incorporado ao monte-partível". Maximiliano, Carlos. Direito das Sucessões, volume III. 2a Ed. Rio de Janeiro: Livraria Editora Freitas Bastos, 1943. p. 441.
} 
em favor de descendente, que ao tempo da doação, não seria chamado à sucessão na qualidade de herdeiro necessário ${ }^{35}$.

A doutrina pátria majoritária entende que deve ser expressa a determinação do testador no sentido de que a doação sairá da parte disponível. Salienta-se, porém, que não há uma forma específica, sacramental para tanto, bastando a manifestação inequívoca do doador de dispensar o herdeiro beneficiado da colação ${ }^{36}{ }_{-} 37$.

Outra questão importante é a que se refere ao valor da liberalidade. O Código Civil, conforme visto acima, afirma que o valor a ser atribuído será aquele do tempo do ato da doação. Entretanto, o Código de Processo Civil, em seu artigo 1.014, afirma que as liberalidades serão calculadas pelo valor que tiverem ao tempo da abertura da sucessão ${ }^{38}$. Este tema será devidamente estudado no capítulo XI.

\footnotetext{
35 "Simulação. Doações transmudadas em empréstimos. Notas promissórias. Simulação entre mãe e filha. Ação de anulação intentada pelo filho e irmão, sob o fundamento de prejuízo na legítima. Simulação configurada em instrumento público de quitação de cambiais e de retificação de declarações de bens para efeito de imposto de renda. Simulação, porém, inocente, não determinante do desfazimento. Legítima que, ao tempo das doações, não foi reduzida, pois até a metade da disponível da donatária. Parecer jurídico neste sentido, baseado em levantamento de auditoria contábil. Autor que, à época das doações, administrava os bens da donatária e não ignorava qual era a metade disponível. Colação afastada em testamento da autora da herança. Recurso desprovido". (TJSP, Ap. n. 7.065.259-8. Relator Desembargador Cerqueira Leite, julgado em 28.02.2007).
}

${ }^{36}$ Nesse sentido: Maximiliano, Carlos. Direito das Sucessões, volume III. 2a Ed. Rio de Janeiro: Livraria Editora Freitas Bastos, 1943. p. 442; Oliveira Leite, Eduardo de. Comentários ao Novo Código Cívil - Do Direito das Sucessões. 5a Ed. Rio de janeiro. Editora GEN/Forense. 2009. p. 925; Rizzardo, Arnaldo. Direito das Sucessões. 6ạ Ed. Rio de janeiro. Editora GEN/Forense. 2011. p. 654; Gomes, Orlando. Sucessões. Rio de Janeiro. 14a Ed. Editora Forense, 2008. p. 291; Dias, Maria Berenice. Manual das Sucessões. 2a Ed. São Paulo. Editora Revista dos Tribunais. 2011. p. 607 e Outros.

37 “A dispensa do dever de colação só se opera por expressa e formal manifestação do doador, determinando que a doação ou ato de liberalidade recaia sobre a parcela disponível de seu patrimônio. Recurso especial não conhecido." (STJ, Resp 730483/MG, Ministra relatora: Nancy Andrighi, Terceira Turma, julgamento em 03/05/2005).

38 Código de Processo Civil, art. 1.014: "No prazo estabelecido no art. 1.000, o herdeiro obrigado à colação conferirá por termo nos autos os bens que recebeu ou, se já os não possuir, trar-lhes-á o valor. Parágrafo único. Os bens que devem ser conferidos na partilha, assim como as acessões e benfeitorias que o donatário fez, calcular-se-ão pelo valor que tiverem ao tempo da abertura da sucessão." (grifamos). 
Por sua vez, quanto ao modo como deve ser dispensada a colação pelo doador, dispõe o artigo 2.006, do Código Civil, que "a dispensa de colação pode ser outorgada pelo doador em testamento, ou no próprio título de liberalidade". Não vale, então, a dispensa virtual, presumida, a inserida em escritura posterior, nem tampouco a declarada oralmente.

Eduardo de oliveira Leite, ao comentar o artigo em tela afirma: "O dispositivo refere-se ao testamento ou ao título da liberalidade. Do próprio título, porque a dispensa importa inclusão da liberalidade na parte disponível, apreciada no momento da abertura da sucessão; de testamento, porque ao testador é lícito deixar a sua metade, a quem escolher e pelo modo que preferir" ${ }^{39}$.

Com efeito, como o testamento é ato revogável por natureza, a dispensa do dever de colacionar pode ser revogada. Basta que no novo testamento o testador revogue a cláusula testamentária anterior, que liberava o herdeiro de colacionar o bem. Dispensada a colação no próprio instrumento de doação, ela pode ser revogada ou imposta posteriormente via testamento ${ }^{40}$.

A liberalidade dispensada de vir à colação considera-se aquela parte disponível que, por estar fora da legítima, é passível de doação, sem prejuízo da cota necessária, pertencente aos herdeiros legítimos. O testador tem a liberdade quanto à disposição da parte disponível e tem direito de deixá-la a quem bem entender. Só não pode prejudicar a legítima dos descendentes.

Entretanto, se a liberalidade exceder a porção disponível do ascendente doador, o excesso se colacionará, a fim de que não haja desigualdade das legítimas. No caso da liberalidade absorver a metade disponível e, ainda, exceder à legítima, sofrerá redução, repondo o donatário o excesso para que se mantenha a perfeita igualdade das legítimas.

\footnotetext{
${ }^{39}$ Oliveira Leite, Eduardo de. Comentários ao Novo Código Civil - Do Direito das Sucessões. 5a Ed. Rio de janeiro. Editora GEN/Forense. 2009. p. 928.

${ }^{40}$ Dias, Maria Berenice. Manual das Sucessões. 2a Ed. São Paulo. Editora Revista dos Tribunais. 2011. p. 607.
} 
Faz-se necessário consignar que constitui fraude o fato de um pai transmitir bens a um ou mais filhos sob a forma societária. Sebastião Amorim e Euclides de Oliveira apresentam o seguinte exemplo: "O pai constitui uma sociedade comercial com dois dos seus três filhos, e somente ele faz aportes reais ao patrimônio da sociedade. Manifesto será o prejuízo do herdeiro excluído, quando da participação da herança do genitor, pois receberá apenas seu quinhão proporcional, enquanto os demais filhos acumularão seus quinhões hereditários com as cotas antes auferidas na sociedade aparente. Será cabível, em tais circunstâncias, desconsiderar a personalidade jurídica da sociedade, para que se reintegre o herdeiro prejudicado na plenitude dos seus direitos legitimários na herança" ${ }^{41}$.

Conforme dito anteriormente, o parágrafo único, do artigo 2.005, do Código Civil, ampliou a incidência de dispensa de colação quando afirma: "Presume-se imputada na parte disponível a liberalidade feita a descendente que, ao tempo do ato, não seria chamado à sucessão na qualidade de herdeiro necessário."

Neste caso, não é necessária qualquer manifestação do doador para que seja dispensada a colação, pois já se presume que a liberalidade saiu da parte disponível. Isto se deve, pois, no momento em que ocorreu a liberalidade, a doação não favorecia herdeiro necessário. O donatário não precisará conferir o bem, mesmo que tenha se tornado herdeiro necessário quando da abertura da sucessão.

O exemplo clássico é o do avô que doa um bem ao neto enquanto ainda vive o pai. A doação ao neto, neste caso, presume-se que saiu da parte disponível. Assim sendo, quando da abertura da sucessão, se forem chamados à herança somente os netos, o que havia sido contemplado não precisa colacionar o bem havido antes de se tornar herdeiro necessário.

\footnotetext{
${ }^{41}$ Amorim, Sebastião e Oliveira, Euclides de. Inventários e Partilhas - Direito das Sucessões - Teoria e Prática. 14a Ed. Editora Universidade do Direito. São Paulo. p.235.
} 


\section{Capítulo VIII - Sujeitos Obrigados à Colação.}

\section{Descendentes.}

A Lei vigente no Brasil não impõe o dever de colação a todos os sucessores necessários, mas, tão somente, aos filhos, ao cônjuge sobrevivente, aos netos (quando representarem seus pais na herança do avô, o mesmo que seus pais teriam que colacionar), aos bisnetos etc. 0 preceito compulsório aplica-se a quaisquer descendentes que sejam herdeiros legítimos e concorram à sucessão de ascendente comum. Conforme dito, a colação tem como escopo a igualação da legítima dos herdeiros.

Adverte, todavia, Zeno Veloso que nem todos os descendentes estão sujeitos à colação, mas somente os que, ao tempo da doação, seriam chamados à sucessão na qualidade de herdeiros necessários (CC, arts. 2.002 e 2.005, parágrafo único $)^{42}$.

Salienta-se, também, que o dever de colacionar imposto ao descendente é mantido, ainda que o outro descendente de mesma classe tenha nascido após o ato de liberalidade. A todos os herdeiros de mesma classe é garantido igual quinhão, mesmo aqueles nascidos após consumação da doação em favor de outro descendente.

Não havendo herdeiros de mesma classe, não há que se falar em dever de colacionar o valor das liberalidades recebidas dos ascendentes. Entretanto, com o nascimento de um herdeiro de mesma classe, tal liberalidade recebida transforma-se em adiantamento de legítima. Sempre que houver outros herdeiros, quer nascido antes do ato de liberalidade, quer nascido depois, existe o dever de conferência ${ }^{43}$.

\footnotetext{
${ }^{42}$ Gonçalves, Carlos Roberto. Direito Civil Brasileiro, volume 7. São Paulo. 5a Ed. Editora Saraiva, 2011. p. 540.

43 “Protesto contra alienação de bens. Deferimento da liminar. Expedição de editais e averbação na matrícula do imóvel. Direitos sucessórios reconhecidos em ação de investigação de paternidade já transitada em julgado. Doação de bem imóvel aos outros filhos. Adiantamento de legítima. Possibilidade de ajuizamento de ação de redução ou colação quando da abertura do inventário, caso tenha sido desrespeitada a legítima. Necessidade de prevenção a direito de terceiros e dos recorrentes. Presença dos pressupostos autorizadores do protesto, que não impede a alienação de bens do de cujus. Decisão mantida. Recurso desprovido. (TJPR, Al 0611658-5, Relator Desembargador Augusto Lopes Cortes, 11a Câmara Cível, publicação em 15.03.2010)".
} 
Ao tratar deste tópico da matéria, Maria Berenice Dias, apresenta o seguinte exemplo: “Na separação, o pai doa a seus filhos o imóvel onde residem. Advindo prole de nova união, quando do falecimento do genitor, o bem doado precisa vir à colação, mesmo que outros herdeiros necessários tenham nascido em momento posterior ao ato de liberalidade. Todos têm direito igual. Cabe atentar somente se o bem doado pertencia em sua integralidade ao doador, ou se metade dele era do ex-cônjuge, a título de meação. Nesta hipótese, só a metade precisa ir à conferência" ${ }^{44}$.

Neste diapasão, percebe-se que os filhos sempre terão o dever de colacionar, por sua vez, quanto aos netos, esta obrigação merece ponderação.

\section{Netos.}

Quando o herdeiro beneficiado morre antes do doador, a obrigação de trazer os bens recebidos à conferência transmite-se a seus descendentes, que comparecem à sucessão em nome do herdeiro pré-morto, conforme dispõe o artigo 2.009, do Código Civil ${ }^{45}$.

Os netos assumem o dever de colacionar quando sucedem por representação os pais, na sucessão dos avós. Isto é, se o netos receberem, por representação, a herança dos pais, deverão colacionar os bens que seus pais colacionariam se vivos estivessem. Este encargo não recai apenas sobre os netos, mas a todos os descendentes, tanto os bisnetos como os demais.

A doutrina majoritária critica veementemente artigo 2.009, do Código Civil, por impor o dever de colação aos netos ainda que não exista mais o bem recebido pelo pai pré-morto.

\footnotetext{
${ }^{44}$ Dias, Maria Berenice. Manual das Sucessões. 2a Ed. São Paulo. Editora Revista dos Tribunais. 2011. p. 597.

${ }^{45}$ Código Civil, artigo 2.009: “Quando os netos, representando os seus pais, sucederem aos avós, serão obrigados a trazer à colação, ainda que não o hajam herdado, o que os pais teriam de conferir."
} 
Mesmo que os filhos não tenham recebido o bem que foi doado ao seu pai, persiste o dever de conferência $^{46}$.

Existem duas hipóteses em que os netos serão obrigados a colacionar na sucessão de seus avós. A primeira, conforme restou consignado acima, trata sobre o dever de colação que recai aos netos quando estes sucedem, por representação, seu pai pré-morto na sucessão de seu avô. Além disto, quando a doação é feita diretamente pelo avô aos netos, e o pai estiver morto, impõe-se o dever de colação aos netos, pois receberam a herança por direito próprio ou por cabeça.

Por sua vez, havendo doação feita diretamente pelo avô aos netos e o pai estiver vivo no momento da sucessão do avô, os netos não devem colacionar, pois não são herdeiros de seu avô (são descendentes de segundo grau). Ademais, em caso de doação feita diretamente pelo avô aos netos, estes também não terão que colacionar o valor desta liberalidade quando, por representação, sucederem seu pai pré-morto na sucessão de seu avô.

Com o intuito de facilitar a didática, colacionamos abaixo o seguinte quadro apresentado por Flávio Tartuce e Luiz Eduardo Simão ${ }^{47}$ :

\begin{tabular}{|l|l|l|}
\hline Partes na doação & $\begin{array}{l}\text { Quem recebeu a herança do } \\
\text { avô }\end{array}$ & Devem colacionar os netos? \\
\hline Doação feita pelo avô ao pai & $\begin{array}{l}\text { Os netos em representação } \\
\text { ao pai pré-morto }\end{array}$ & $\begin{array}{l}\text { Sim. Se o pai vivo fosse, } \\
\text { deveria colacionar; então os }\end{array}$ \\
\hline
\end{tabular}

\footnotetext{
${ }^{46}$ Nesse sentido: “Não é justo, como observa Astolpho Rezende, que o neto fique sujeito a colacionar haveres que seu pai desbaratou, por infeliz ou perdulário, arcando destarte com as conseqüências e sendo compelido a conferir por outrem o que em verdade não recebeu. E mais injusto, ainda, se se atentar em que, na transmissão a estranhos cessa este dever". Silva Pereira, Caio Mário. Instituições de Direito Civil, Volume VI. 18a Ed. Rio de Janeiro: GEN/Editora Forense, 2010. p. 374.

${ }^{47}$ Tartuce, Flávio e Simão, José Fernando. Direito Civil: Direito das Sucessões, vol. 6. 1ạ Ed. Rio de janeiro. Editora GEN/Forense. 2007. p. 413
} 


\begin{tabular}{|l|l|l|}
\hline & & $\begin{array}{l}\text { netos, como representantes, } \\
\text { devem colacionar. }\end{array}$ \\
\hline $\begin{array}{l}\text { Doação feita diretamente } \\
\text { pelo avô aos netos }\end{array}$ & $\begin{array}{l}\text { Os netos, por direito próprio, } \\
\text { e não por representação }\end{array}$ & $\begin{array}{l}\text { Sim. Os netos deverão } \\
\text { colacionar os bens que } \\
\text { receberam. }\end{array}$ \\
\hline $\begin{array}{l}\text { Doação feita diretamente } \\
\text { pelo avô aos netos }\end{array}$ & $\begin{array}{l}\text { O pai, pois está vivo no } \\
\text { momento da sucessão do avô }\end{array}$ & $\begin{array}{l}\text { Não. Os netos não devem } \\
\text { colacionar, pois não são } \\
\text { herdeiros de seu avô. }\end{array}$ \\
\hline $\begin{array}{l}\text { Doação feita diretamente } \\
\text { pelo avô aos netos }\end{array}$ & $\begin{array}{l}\text { Os netos em representação } \\
\text { ao pai pré-morto }\end{array}$ & $\begin{array}{l}\text { Não. Os netos não devem } \\
\text { colacionar os bens, pois, na } \\
\text { sucessão, estão representando } \\
\text { seu pai falecido. }\end{array}$ \\
\hline
\end{tabular}

3. Colação das doações realizadas por ambos os cônjuges, em favor de descendente comum.

Este é mais um caso no qual o sujeito obrigado à colação é descendente, porém, diante da sua especialidade, mereceu o devido destaque. Isto, pois, agora, refere-se à doação feita por ambos os cônjuges, ascendentes, em favor de descendente.

Se a doação tiver sido feita por um só dos cônjuges, apenas em seu inventário deverá ser colacionada a doação. Entretanto, no caso de doação feita por ambos os cônjuges, no inventário de cada um se conferirá por metade, conforme dispõe o artigo 2.012, do Código Civil $^{48}$.

A justificativa para a regra é que se presume ter cada um dos ascendentes efetuado metade da doação. Embora feita por ambos os cônjuges em favor de descendente comum, trata-se, na verdade, de duas liberalidades antecipatórias da herança: a paterna e a materna.

\footnotetext{
${ }^{48}$ Código Civil, artigo 2.012: "Sendo feita a doação por ambos os cônjuges, no inventário de cada um se conferirá por metade".
} 
Presume-se que cada doador efetuou a gratificação com relação à metade do bem. Por essa razão, no inventário de cada um dos cônjuges se conferirá o que for doado por metade.

Não restam quaisquer dúvidas, em face do estabelecido pelo artigo 226, parágrafo terceiro, da Constituição Federal, e dos artigos 1.723 e seguintes do Código Civil, que o dispositivo em apreço é aplicável à hipótese de a doação ser feita ao descendente por ambos os companheiros, se a família é constituída por união estável.

\section{Cônjuge sobrevivente.}

Com o advento do novo Código Civil, surgiu a dúvida se o cônjuge sobrevivente é obrigado ou não a colacionar os bens recebidos pelo de cujus. Tal dúvida é fruto da incongruência entre os artigos, 544, 2.002 e 2.003 do referido diploma legal.

Inicialmente, vale lembrar que o artigo 544 estabelece: "a doação de ascendente a descendente, ou de um cônjuge a outro, importa adiantamento, do que lhes cabe por herança".

Por sua vez, o artigo 2.002 dispõe que apenas os descendentes são obrigados, para igualar a legítima, a colacionar o valor das doações, que dele em vida receberam, silenciando, assim, se o cônjuge sobrevivente possui este dever ou não.

Entretanto, diante da leitura do artigo 2.003, extrai-se que a colação tem por finalidade igualar as legítimas dos descendentes e do cônjuge sobrevivente. Isto é, o artigo 2.002 refere-se apenas aos descendentes, porém no artigo subsequente reporta-se ao cônjuge sobrevivente, resgatando a ideia da necessidade de conferência das liberalidades feitas também ao cônjuge sobrevivente e que por disposição legal são consideradas adiantamento de legítima (CC, art. 544). 
A doutrina majoritária, diante deste impasse, pende no sentido de que tanto os descendentes quanto o cônjuge sobrevivente são obrigados a colacionar o valor da doação, por força dos artigos, 2.002, 2.003 e 544, do Código Civil ${ }^{49}$.

Para encerrar este impasse, revela observar que o dever de colacionar, quanto ao cônjuge restringe-se à hipótese em que deva concorrer com descendentes. Havendo restrição quanto ao regime de bens, o cônjuge sobrevivente só deverá colacionar os bens recebidos por doação de seu consorte quando concorrer à sucessão nos casos previstos nos artigos 1.829, inciso I, e 1.832, do diploma civil. Não está ele sujeito à colação quando participa sozinho, pois não faria sentido, nem quando concorre com ascendentes, já que estes também não são $50{ }^{5}{ }^{5}$.

\section{Colação pelo renunciante ou excluído da herança.}

Tanto no Código Civil atual, como no de 1916, os herdeiros renunciantes e excluídos da sucessão não perdem aquilo que receberam em forma de doação ou liberalidade pelo de cujus, em vida. Perdem tão somente o que, da doação, exceder do que tinha direito como legítima, e a parte doação que ultrapassar a metade disponível do defunto. Estes excessos retornarão ao monte-partível e só beneficiarão os herdeiros remanescentes.

\footnotetext{
${ }^{49}$ Nesse sentido: Oliveira Leite, Eduardo de. Comentários ao Novo Código Civil - Do Direito das Sucessões. 5a Ed. Rio de janeiro. Editora GEN/Forense. 2009. p. 914; Rizzardo, Arnaldo. Direito das Sucessões. 6a Ed. Rio de janeiro. Editora GEN/Forense. 2011. p. 648; Gomes, Orlando. Sucessões. Rio de Janeiro. 14a Ed. Editora Forense, 2008. p. 292; Dias, Maria Berenice. Manual das Sucessões. 2a Ed. São Paulo. Editora Revista dos Tribunais. 2011. p. 594 e Outros.

${ }^{50}$ Gonçalves, Carlos Roberto. Direito Civil Brasileiro, volume 7. São Paulo. 5a Ed. Editora Saraiva, 2011. p. 540.

${ }^{51}$ Código Civil, artigo 1.829, caput e inciso I: “Art. 1.829. A sucessão legítima defere-se na ordem seguinte: I - aos descendentes, em concorrência com o cônjuge sobrevivente, salvo se casado este com o falecido no regime da comunhão universal, ou no da separação obrigatória de bens (art. 1.640, parágrafo único); ou se, no regime da comunhão parcial, o autor da herança não houver deixado bens particulares;". Artigo 1.832: “Em concorrência com os descendentes (art. 1.829, inciso I) caberá ao cônjuge quinhão igual ao dos que sucederem por cabeça, não podendo a sua quota ser inferior à quarta parte da herança, se for ascendente dos herdeiros com que concorrer."
} 
Esta conclusão é retirada do artigo 2.008 (art. 1.790, CC/1916): “Aquele que renunciou à herança ou foi dela excluído, deve, não obstante, conferir as doações recebidas, para o fim de repor o que exceder o disponível."

Equiparando o renunciante ao indigno, o Código Civil retoma o princípio da igualdade das legítimas, exigindo que o herdeiro confira a doação recebida, ainda que ele tenha renunciado à herança, pois a liberalidade pode ser de tal monta que absorva a porção disponível do doador e mais a parte, que caberia ao descendente como legítima. Para evitar tal ocorrência, o texto legal impõe a colação, pois sem a conferência ficariam desfalcadas as legítimas dos demais herdeiros e o favorecido, renunciando a herança, já teria garantida, via doação recebida e não colacionada, porção maior que na legítima do que os demais ${ }^{52}$.

É lícito ao renunciante e ao indigno permanecerem com a doação que não exceda a quota disponível, e que não abranja a parte legítima, a qual não possui direito (CC, art. 1.814).

A idéia é clara: se a colação é obrigatória para igualar as legítimas (CC, art. 2.003) e se à legítima não tem direito o excluído (CC, art. 1.814), não pode este reter bens doados que valham a legítima, mais a metade disponível, pois, se assim fosse, ocorreria uma posição mais favorável que a dos herdeiros não excluídos.

Como inteligentemente afirma Carlos Maximiliano, o Código Civil incidiu em impropriedade tecnológica ${ }^{53}$. Isto, pois, o que o artigo 2.008 chama de conferir, deveria ser chamado de reduzir. Conferir é somar ao acervo líquido, com finalidade de partilhar e, jamais, podar o demasiado.

\footnotetext{
${ }^{52}$ Oliveira Leite, Eduardo de. Comentários ao Novo Código Civil - Do Direito das Sucessões. 5 a Ed. Rio de janeiro. Editora GEN/Forense. 2009. p. 934.

53 “A obrigação de conferir liberalidades incumbe ao que é herdeiro; o renunciante não o é; portanto está isento da mesma. Apenas oferece os bens havidos do de cujus, afim de se reduzirem as dádivas, em relação à parte em que se excedam a soma da legítima, do beneficiado, com a metade disponível do espólio. O Código Civil chama a isto conferir, incidindo em impropriedade tecnológica. Em verdade, conferir é somar ao acervo líquido, afim de partilhar; não é - podar o demasiado". Maximiliano, Carlos. Direito das Sucessões, volume III. 2a Ed. Rio de Janeiro: Livraria Editora Freitas Bastos, 1943. p. 432.
} 
Na mesma esteira do Código Civil, dispõe o artigo 1.015, do Código de Processo Civil, que o herdeiro que renunciou a herança, ou o que dela foi excluído, não está isento de conferir, para repor a parte inoficiosa, as liberalidades que houver recebido do doador ${ }^{54}$.

Nestes casos, o donatário poderá escolher os bens doados, tantos quantos bastarem para perfazer a legítima e a metade disponível, entrando na partilha o excedente para ser dividido entre os demais (CPC, art. 1.015, §1ㅇ). Outra hipótese, se a parte inoficiosa recair sobre bem imóvel que seja indivisível, ou não comporte divisão cômoda, proceder-se-á a licitação entre os herdeiros, tendo o donatário preferência em igualdade de condições aos demais herdeiros, desde que não seja vulnerado o princípio da igualdade de quinhões (CC, art. 1.015, § 2ㅇ).

Resumindo: os herdeiros excluídos por deserdação, ou indignidade, bem como o renunciante devem conferir as doações recebidas, para reposição da parte inoficiosa.

\section{Excluídos da obrigação colacional.}

Conforme dito anteriormente, o instituto da colação é peculiar à sucessão legítima. A sua finalidade é igualar as porções legítimas. Assim sendo, são os herdeiros necessários os destinatários deste instituto, mais precisamente, os descendentes e o cônjuge sobrevivente.

Diante disto, são excluídos da obrigação imposta pela colação os ascendentes, os colaterais, os legatários, os herdeiros testamentários e os estranhos.

\footnotetext{
${ }^{54}$ Código de Processo Civil, artigo 1.015: "O herdeiro que renunciou à herança ou o que dela foi excluído não se exime, pelo fato da renúncia ou da exclusão, de conferir, para o efeito de repor a parte inoficiosa, as liberalidades que houve do doador. $\S 1^{\circ}$ E lícito ao donatário escolher, dos bens doados, tantos quantos bastem para perfazer a legítima e a metade disponível, entrando na partilha o excedente para ser dividido entre os demais herdeiros. $\S 2^{\circ}$ Se a parte inoficiosa da doação recair sobre bem imóvel, que não comporte divisão cômoda, o juiz determinará que sobre ela se proceda entre os herdeiros à licitação; o donatário poderá concorrer na licitação e, em igualdade de condições, preferirá aos herdeiros."
} 
Qualquer doação feita em favor de qualquer uma das pessoas acima, ainda que a liberalidade exceda, em valor, a quota disponível, não se dá colação, porém simples redução, nos moldes do artigo 2.007, do Código Civil. 


\section{Capítulo IX - Legitimidade Para Pedir a Colação.}

Somente os herdeiros necessários podem pedir a colação de bens recebidos por outros descendentes ou pelo cônjuge sobrevivente, embora o favorecido com a liberalidade deva conferi-la independentemente de interpelação judicial.

Assim sendo, ficam excluídos de pedir a colação os colaterais, os credores, os herdeiros testamentários, os legatários, os que renunciarem à herança e os que foram dela excluídos.

Quanto à possibilidade dos credores serem legitimados para pedir a colação, entende-se que, havendo fraude ou má-fé, a questão muda um pouco de visão. No caso de herdeiro que contraia dívidas e, com efeito, transfira seus bens frutos de liberalidades, admite-se que os credores habilitem-se, não propriamente para pedir a colação, mas sim a ingressar com a ação pauliana, com a finalidade de anular as liberalidades e as vendas (CC, arts. 158, 159 e 161).

O renunciante e o excluído da herança não podem reclamar a colação, pois não são mais herdeiros necessários.

Aos herdeiros testamentários e legatários também não cabe tal prerrogativa, ainda que, após o testamento, seu autor tenha feito doações que atinjam a parte disponível. Isto se deve, pois, com a ocorrência de doações posteriores, automaticamente fica revogado o testamento, pelo menos na parte abrangida por aquele tipo de liberalidade. Vale lembrar que a disposição testamentária é revogável até o momento da morte do testador.

O testamenteiro não possui legitimidade para pedir a colação, tendo em vista que este ato cabe apenas aos herdeiros necessários ${ }^{55}$.

\footnotetext{
${ }^{55}$ Processo Civil - Agravo de Instrumento - Direito de exigir colação em pleito sucessório - Herdeiros Necessários Jurisprudência do STJ. I - O direito de exigir colação é privativo dos herdeiros necessários, a teor do art. 1.785 do CCB - llegitimidade de o testamenteiro exigir a colação, a fim de possibilitar imputação legitimária - recurso provido. II - Matéria de fato (Súmula 07/STJ). III - Recursos não conhecidos. (Resp. n.o 170.037/SP, Ministro Relator Waldemar Zveiter, Terceira Turma, julgado em 13.04.1999)
} 
Basta apenas um legitimado protestar para que, sendo provada a sonegação, o herdeiro omisso incorra nas sanções legais. 


\section{Capítulo X - Objeto.}

No curso desta obra, vimos que, em tese, todas as doações e liberalidades feitas, em vida, por ascendente, em favor de descendente ou do cônjuge sobrevivente devem ser colacionadas. Entretanto, existem alguns casos em que certas liberalidades são dispensadas de colação. Com intuito eminentemente didático, dedicamos este capítulo para elucidar quais são bens sujeitos à colação e quais são excluídos da conferência colacional.

\section{1- Bens sujeitos à colação.}

São sujeitos à obrigação conferencial os bens doados a herdeiros necessários (descendentes e cônjuge sobrevivente). Até o falecimento do doador, o bem pertence ao donatário com exclusividade. No momento em que morre o doador, os bens da sucessão passam a todos os herdeiros de forma indivisa, em condomínio (CC, art. 1.791, parágrafo único $)^{56}$. Como houve adiantamento da legítima, a quota hereditária doada precisa ser trazida à colação.

Em linhas gerais a doutrina considera que devem ser trazidos à colação os seguintes bens:

(i) As doações constituídas pelo ascendente.

(ii) Doações dos avós aos netos, quando eles concorrerem a herança com tios ou primos.

(iii) Doações recebidas pelos pais, quando estes falecerem antes do doador e forem representados pelo sucessor.

\footnotetext{
56 Código Civil, artigo 1.791: “Art. 1.791. A herança defere-se como um todo unitário, ainda que vários sejam os herdeiros. Parágrafo único. Até a partilha, o direito dos co-herdeiros, quanto à propriedade e posse da herança, será indivisível, e regular-se-á pelas normas relativas ao condomínio". ${ }^{57}$ Neste sentido: Maximiliano, Carlos. Direito das Sucessões, volume III. 2a Ed. Rio de Janeiro: Livraria Editora Freitas Bastos, 1943. p. 448. e Silva Pereira, Caio Mário. Instituições de Direito Civil, Volume VI. 18a Ed. Rio de Janeiro: GEN/Editora Forense, 2010. p. 376.
} 
(iv) Venda de bens ou doações feitas por interposta pessoa, com o intuito de prejudicar a legítima dos herdeiros do autor da herança.

(v) Recursos fornecidos pelo ascendente, para que o descendente pudesse adquirir bens.

(vi) Dinheiro colocado a juros pelo ascendente em nome do descendente ou do cônjuge sobrevivente.

(vii) Quantias desembolsadas pelo pai para pagar débito de filho ou do cônjuge sobrevivente.

(viii) Valor da dívida do descendente, remitida pelo pai

(ix) As doações verbais e coisas de pequeno valor, embora não seja de uso tal conferência ${ }^{57}{ }^{58}$.

(x) Se ao tempo do falecimento do doador o herdeiro beneficiado não mais tiver o bem recebido, ainda assim deve trazer à colação o seu valor.

(xi) Doações indiretas - Estas são negócios jurídicos que não tem a natureza e a forma de doações. As doações indiretas são "doações mascaradas".

\footnotetext{
57 Neste sentido: Maximiliano, Carlos. Direito das Sucessões, volume III. 2ạ Ed. Rio de Janeiro: Livraria Editora Freitas Bastos, 1943. p. 448. e Silva Pereira, Caio Mário. Instituições de Direito Civil, Volume VI. 18a Ed. Rio de Janeiro: GEN/Editora Forense, 2010. p. 376.

58 Em sentido contrário: "Correspondem a uma prática comum, que mais significa sentimento de afeto e apoio aos filhos e a o cônjuge. Entram nesta ordem as doações de moveis, de instrumentos profissionais, de eletrodomésticos, roupas, e coisas de uso diário". Rizzardo, Arnaldo. Direito das Sucessões. 6a Ed. Rio de janeiro. Editora GEN/Forense. 2011. p. 656.
} 
Não só as doações feitas diretamente ao herdeiro, como também as indiretas devem ser trazidas à colação. A doação feita por interposta pessoa física ou jurídica configura simulação. Existem algumas artimanhas que configuram doações indiretas ou simuladas como, por exemplo, o pagamento de dívida de herdeiro necessário; a renúncia a algum direito; a remissão de dívida; a compra de bem em nome dele; construção de prédio em terreno de descendente ${ }^{59}$.

Conforme dito anteriormente, quando por meio de planejamento sucessório é feita a transferência de bens somente a algum herdeiro necessário em detrimento dos demais cabe a aplicação dos princípios da disregard, que autorizam a desconsideração da personalidade jurídica (CC, art. 50).

\section{2- Bens e despesas excluídos da conferência colacional.}

(i) As despesas ordinárias do ascendente com o descendente, enquanto menor.

O artigo 2.010, do Código Civil, dispensa de colação os gastos normais de ascendente com descendente, enquanto menor, na sua educação, estudos, sustento, vestuário, tratamento

\footnotetext{
59 "Civil e processual. Acórdão estadual. Nulidade não configurada. Ação de reconhecimento de simulação cumulada com ação de sonegados. Bens adquiridos pelo pai, em nome dos filhos varões. Inventário. Doação inoficiosa indireta. Prescrição. Prazo vintenário, contado da prática de cada ato. Colação dos próprios imóveis, quando ainda existem no patrimônio dos réus. Exclusão das benfeitorias por ele realizadas. CC anterior, arts. 177, 1.787 E 1.732, § 2‥ Sucumbência recíproca. Redimensionamento. CPC, ART. 21. I. Não padece de nulidade o acórdão que enfrentou as questões essenciais ao julgamento da controvérsia, apenas com conclusões desfavoráveis à parte. II. Se a aquisição dos imóveis em nome dos herdeiros varões foi efetuada com recursos do pai, em doação inoficiosa, simulada, em detrimento dos direitos da filha autora, a prescrição da ação de anulação é vintenária, contada da prática de cada ato irregular. III. Achando-se os herdeiros varões ainda na titularidade dos imóveis, a colação deve se fazer sobre os mesmos e não meramente por seu valor, ao teor dos arts. 1.787 e 1.792, parágrafo 20, do Código Civil anterior. IV. Excluem-se da colação as benfeitorias agregadas aos imóveis realizadas pelos herdeiros que os detinham (art. 1.792, parágrafo 20). V. Sucumbência recíproca redimensionada, em face da alteração decorrente do acolhimento parcial das teses dos réus. VI. Recurso especial conhecido em parte e provido". (STJ, Resp 259406/PR, Relator Ministro Aldir Guimarães Passarinho Júnior, Quarta Turma, julgado em 17.02.2005).
} 
nas enfermidades, enxoval, assim como as despesas de casamento, ou as feitas no interesse de sua defesa em processo-crime ${ }^{60}$.

Estes gastos ordinários não constituem doação, porque não aumentam o patrimônio dos filhos. Ademais, estas despesas correspondem ao cumprimento de obrigação natural imposta pelo direito aos pais (CC, art. 1.568), motivo pelo qual não há que se falar em colação $^{61}$.

Gastos ordinários são aqueles costumeiros, em conformidade com as possibilidades econômicas do ascendente. Havendo excesso, ou considerável diminuição do patrimônio do ascendente, perdem o caráter de ordinários e devem ser colacionados.

O dispositivo citado deixa claro que não são colacionáveis as despesas ordinárias feitas em favor de descendentes menores. Atingida a maioridade os descendentes passam a ser capazes de sustentarem-se sozinhos, razão pela qual qualquer gasto que o ascendente tenha com o descendente que antes era considerado ordinário, a partir de agora, terá o caráter de doação.

Ressalva-se, entretanto, que não é colacionável a pensão alimentícia prestada por ascendente, em favor de descendente maior, em decorrência de efetiva e demonstrada necessidade (CC, arts. 1.695 e 1.696$)^{62}$.

\footnotetext{
${ }^{60}$ Código Civil, artigo 2.010: "Não virão à colação os gastos ordinários do ascendente com o descendente, enquanto menor, na sua educação, estudos, sustento, vestuário, tratamento nas enfermidades, enxoval, assim como as despesas de casamento, ou as feitas no interesse de sua defesa em processo-crime."

${ }^{61}$ Código Civil, artigo 1.568: "Os cônjuges são obrigados a concorrer, na proporção de seus bens e dos rendimentos do trabalho, para o sustento da família e a educação dos filhos, qualquer que seja o regime patrimonial."

${ }^{62}$ Código Civil, artigo Art. 1.695. "São devidos os alimentos quando quem os pretende não tem bens suficientes, nem pode prover, pelo seu trabalho, à própria mantença, e aquele, de quem se reclamam, pode fornecê-los, sem desfalque do necessário ao seu sustento". Art. 1.696. "O direito à prestação de alimentos é recíproco entre pais e filhos, e extensivo a todos os ascendentes, recaindo a obrigação nos mais próximos em grau, uns em falta de outros."
} 
(ii) Doações remuneratórias de serviços prestados aos ascendentes.

Por força do artigo 2.011, do Código Civil, "as doações remuneratórias de serviços feitos ao ascendente também não estão sujeitas à colação".

As doações remuneratórias visam recompensar serviços, para os quais não se convencionou preço ou salário. Traduzem, então, uma forma de recompensa que é arbitrada e dada pelo ascendente beneficiado com serviço, em favor do ascendente prestador do serviço.

A observação que não pode faltar é que se for exacerbado o montante, ou muito acima da estimativa dos serviços, sobressai à doação, pelo menos na parcela excedente, impondo a colação ${ }^{63}$.

(iii) Os frutos produzidos pelos bens doados.

Frutos e rendimentos do objeto da liberalidade, quer os percebidos antes, quer os colhidos ou recebidos depois do óbito; assim como os móveis ou imóveis adquiridos com a renda dos bens dados ou doados, não se conferem; não entram no cômputo da legítima geral ${ }^{64}$.

Entretanto, parte da doutrina, entende que apenas não são colacionáveis os frutos produzidos pelos bens doados até a data do falecimento do autor da herança, momento em que é aberta a sucessão. Esta parcela doutrina assim entende por analogia ao artigo 2.020, do Código Civil, onde consta que os herdeiros, o cônjuge sobrevivente e o inventariante "são obrigados a trazer ao acervo os frutos que perceberem desde a abertura da sucessão" ${ }^{65}$.

\footnotetext{
${ }^{63}$ Rizzardo, Arnaldo. Direito das Sucessões. 6a Ed. Rio de janeiro. Editora GEN/Forense. 2011. p. 655.

${ }^{64}$ Maximiliano, Carlos. Direito das Sucessões, volume III. 2a Ed. Rio de Janeiro: Livraria Editora Freitas Bastos, 1943. p. 455.

65 Código Civil, artigo 2.020: “Os herdeiros em posse dos bens da herança, o cônjuge sobrevivente e o inventariante são obrigados a trazer ao acervo os frutos que perceberam, desde a abertura da sucessão; têm direito ao reembolso das despesas necessárias e úteis que fizeram, e respondem pelo dano a que, por dolo ou culpa, deram causa."
} 
A questão não é pacífica, mas entendemos que não cabem nem a colação dos frutos e rendimentos posteriores à abertura da sucessão do de cujus, a menos que se prove a posse de má-fé ${ }^{66}$. No mínimo, era o descendente favorecido um possuidor de boa-fé, ficando obrigado na regra do artigo 1.214 , do Código Civil, que assegura o direito aos frutos percebidos ao possuidor de boa-fé ${ }^{67}$.

Nas palavras sempre precisas de Carlos Maximiliano "até falecer o de cujus, todo indivíduo opulentado com um ato benéfico é, enquanto se não prova o contrário, considerado possuidor de boa-fé; em consequência, não confere o fruto das coisas que the deu o ascendente" ${ }^{\prime 68}$.

(iv) As benfeitorias introduzidas nos bens doados.

Benfeitorias acrescidas nos bens doados, após a entrega de doação, pertencem ao beneficiado. Está é a orientação contida no parágrafo 2ํ, do artigo 2.004, do Código Civil: "Só o valor dos bens doados entrará em colação; não assim o das benfeitorias acrescidas, as quais pertencerão ao herdeiro donatário, correndo também à conta deste os rendimentos ou lucros, assim como os danos e as perdas que eles sofreram".

As benfeitorias acrescidas não entram no cômputo da parte legítima, nem da parte disponível. Não estão sujeitas à colação. Em consequência desta regra, se a coisa reintegrada no acervo não couber toda, em partilha, ao que a recebeu do de cujus vivo, os aquinhoados

\footnotetext{
${ }^{66}$ Nesse sentido: Maximiliano, Carlos. Direito das Sucessões, volume III. 2a ${ }^{2}$ Ed. Rio de Janeiro: Livraria Editora Freitas Bastos, 1943. p. 455; Rizzardo, Arnaldo. Direito das Sucessões. 6a Ed. Rio de janeiro. Editora GEN/Forense. 2011. p. 655 e Silva Pereira, Caio Mário. Instituições de Direito Civil, Volume VI. 18a Ed. Rio de Janeiro: GEN/Editora Forense, 2010. p. 377.

${ }^{67}$ Código Civil, artigo 1.214: "O possuidor de boa-fé tem direito, enquanto ela durar, aos frutos percebidos. Parágrafo único. Os frutos pendentes ao tempo em que cessar a boa-fé devem ser restituídos, depois de deduzidas as despesas da produção e custeio; devem ser também restituídos os frutos colhidos com antecipação".

${ }^{68}$ Maximiliano, Carlos. Direito das Sucessões, volume III. 2a Ed. Rio de Janeiro: Livraria Editora Freitas Bastos, 1943. p. 456.
} 
com o restante pagarão ao conferente as benfeitorias úteis e as necessárias, proporcionalmente às partes que lhe tocarem ${ }^{69}$.

(v) Os seguros de vida instituídos em favor de descendentes e do cônjuge.

Não são colacionáveis nem os prêmios pagos e nem o próprio seguro a ser recebido pelo beneficiário, uma vez em que o contrato foi celebrado sem a participação do mesmo.

Quanto aos prêmios, além de se constituírem os valores de quantias módicas, nenhuma lei os considera como adiantamento de legítima. E no pertinente ao seguro em si, o pagamento efetua-se pela seguradora, não repercutindo no patrimônio do de cujus $^{70}{ }_{-}^{71}$.

(vi) Empréstimos gratuitos de bens.

Os empréstimos gratuitos de bens não são colacionáveis. Além destes, também não devem ser conferidos o usufruto, o comodato, a servidão temporária e o uso. $O$ fundamento da não obrigatoriedade de colação dá-se pelo fato de não configurarem doações. Ademais, é complicado estimar quanto economicamente estes empréstimos prejudicaram a legítima dos co-herdeiros.

(vii) Por ato de vontade dos co-herdeiros, em favor do donatário.

Os herdeiros que foram beneficiados com uma doação feita pelo ascendente, em vida, podem ser liberados do encargo da colação se assim desejarem os co-herdeiros. Para que

\footnotetext{
${ }^{69}$ Maximiliano, Carlos. Direito das Sucessões, volume III. 2a Ed. Rio de Janeiro: Livraria Editora Freitas Bastos, 1943. p. 456.

${ }^{70}$ Rizzardo, Arnaldo. Direito das Sucessões. 6a Ed. Rio de janeiro. Editora GEN/Forense. 2011. p. 656.

${ }^{71}$ Em sentido contrário: "No caso do seguro de vida, o filho confere as prestações ou anuidades com que a favor dele entrou o progenitor; foram estas quantias que saíram do patrimônio do ascendente em proveito, não o prêmio pago pela companhia". Maximiliano, Carlos. Direito das Sucessões, volume III. 2a Ed. Rio de Janeiro: Livraria Editora Freitas Bastos, 1943. p. 453.
} 
possam liberar o donatário deste encargo, os co-herdeiros precisam ser capazes e livres para manifestarem sua vontade.

Neste sentido, afirma Carlos Maximiliano: “Ao autor da liberalidade, e só a ele, incumbe a prerrogativa de conceder a dispensa referida, embora aos co-herdeiros, se todos são juridicamente capazes, assista a faculdade ampla de libertar da injunção legal o beneficiado, transigir sobre o assunto, nada exigir, ou assinar desistência ou renúncia concernente a reclamação já iniciada"72.

(viii) Por perecimento do bem doado sem culpa do beneficiado.

A doutrina entende que se o bem recebido em doação perece sem que haja culpa do herdeiro beneficiado, ou seja, por fortuito ou força maior, este não está sujeito a conferir-lhe o valor no inventário do doador. Isto ocorre, pois, nestes casos, vigora a presunção de que o perecimento ocorreria independentemente da doação. Entretanto, se for culposa a perda, subsiste a obrigação de colacionar o bem ou seu valor em dinheiro ${ }^{73}$.

\footnotetext{
${ }^{72}$ Maximiliano, Carlos. Direito das Sucessões, volume III. 2ª Ed. Rio de Janeiro: Livraria Editora Freitas Bastos, 1943. p. 442.

${ }^{73}$ Neste Sentido: Silva Pereira, Caio Mário. Instituições de Direito Civil, Volume VI. 18a Ed. Rio de Janeiro: GEN/Editora Forense, 2010. p. 377; Maria Berenice. Manual das Sucessões. 2a Ed. São Paulo. Editora Revista dos Tribunais. 2011. p. 599 e Outros.
} 


\section{Capítulo XI - Modos de Realização da Colação.}

Existem dois modos de levar à conferência as doações recebidas, o primeiro modo é o da colação por substância e o segundo é o da colação por estimação.

A teoria da colação por substância ou in natura considera que bem doado é restituído ao monte partível, desconstituindo-se, então, a doação. Assim, cabe atribuir-lhe o valor ao tempo da abertura da sucessão

Por outro lado, a teoria da colação por estimação ou pelo valor sustenta que o cálculo do valor da doação deve ser feito pelo valor estimativo à época da liberalidade. O herdeiro não traz o bem à sucessão, apenas computa o seu valor para simples conferência.

Surpreendentemente, o Código Civil de 2.002 parece adotar as duas teorias. Prevalece na doutrina a teoria da estimação e só alternativamente a da substância (CC, art. 2.003, $\S$ único) $)^{74}{ }^{75}$.

Em regra, a colação se faz pelo valor das doações (CC, art. 2.002), ou seja, o valor certo ou estimado que conste do ato de liberalidade (CC, art. 2.004). Se não constar o valor, estimase o que valia naquela época (CC, art. 2.004, § 1ㅇ).

Ainda que haja a indicação do valor, pode ser determinada a avaliação para identificar o valor real do bem à data da doação. Basta ficar evidenciado que o quantum indicado no documento da doação não corresponde ao efetivo valor da data em que houve a transmissão.

\footnotetext{
${ }^{74}$ Nesse sentido: Silva Pereira, Caio Mário. Instituições de Direito Civil, Volume VI. 18a Ed. Rio de Janeiro: GEN/Editora Forense, 2010. p. 379; Rodrigues, Sílvio. Direito Civil, Direito das Sucessões, Volume 7. 26a Ed. Saraiva, 2003. p. 317 e Gomes, Orlando. Sucessões. Rio de Janeiro. 14a Ed. Editora Forense, 2008. p. 295.

${ }^{75}$ Em sentido contrário: "A conferência de bens em substância atende mais ao espírito de justiça, pois, em fase de inflação galopante, o valor em dinheiro dos bens avaliados no passado nem sempre representa a vantagem patrimonial existente no momento da abertura da sucessão, desatendendo-se, assim, ao princípio da igualdade dominante no direito sucessório". Oliveira Leite, Eduardo de. Comentários ao Novo Código Civil - Do Direito das Sucessões. 5ạ Ed. Rio de janeiro. Editora GEN/Forense. 2009. p. 916. Assim também pensa: Maximiliano, Carlos. Direito das Sucessões, volume III. 2a Ed. Rio de Janeiro: Livraria Editora Freitas Bastos, 1943. p. 462.
} 
Não se trata de avaliar o bem à data da abertura da sucessão, mas identificar quanto valia em dinheiro à data da doação, corrigindo-se o montante encontrado. É indispensável incidir à correção monetária para se chegar a valores homogêneos.

Por sua vez, a teoria da colação por substância ou in natura é utilizada, de forma excepcional, nos seguintes casos: (i) quando não houver no monte bens suficientes para igualar a legítima dos descendentes ou do cônjuge sobrevivente (CC, art. 2.003, § único). (ii) quando for constatada que a doação é inoficiosa, a restituição do excesso será em substância (CC, art. $2.007, \S 2 \circ)$. 


\section{Capítulo XII - Do Valor dos Bens Doados.}

A colação tem por finalidade verificar se as liberalidades feitas pelo autor da herança obedeceram ao limite legal, qual seja, a metade dos bens em caso de possuir herdeiros necessários. Daí a necessidade de apurar o valor das doações.

Diante disto, será iniciada, talvez, no tópico mais controverso do instituto da colação. Sempre gerou muita controvérsia se deveria ser utilizado como critério de avaliação do valor das liberalidades, o momento em que ocorre a doação, ou se o mais adequado seria calcular o valor do bem no momento da abertura da sucessão.

$\mathrm{Na}$ doutrina brasileira sempre dominou o princípio de que os bens doados tinham de ser colacionados com o valor que era o deles na data do ato jurídico gratuito. Isto é o que afirmava o caput do antigo artigo 1.792, do Código Civil de 1916: "Os bens doados, ou dotados, imóveis, ou móveis, serão conferidos pelo valor certo, ou pela estimação que deles houver sido feita na data da doação".

Com o advento do Código de Processo Civil de 1973, este entendimento modificou-se ${ }^{76}$, pois foi revogado o referido artigo do Código Civil de 1916. Isto se deve pela regra estabelecida pelo parágrafo único do artigo 1.014 do CPC: "Os bens que devem ser conferidos na partilha, assim como as cessões e benfeitorias que o donatário fez, calcular-se-ão pelo valor que tiverem ao tempo da abertura da sucessão".

Diante desta regra, todos os bens são avaliados, em conjunto, na data da abertura da sucessão, para que seja garantida a igualdade na partilha. A ideia que, naturalmente, decorria do texto legal do Código Civil de 1916 e que atendia aos ditames do processo inflacionário era a

\footnotetext{
76 "Partilha. Avaliação contemporânea de todos os bens. Artigos 1792 do Código Civil e 1014 do Código de Processo Civil. O princípio da igualdade da partilha conduz a avaliação contemporânea de todos os bens, especialmente em face da inflação existente no país. Preclusão inocorrente, em vista da natureza continuativa do inventário. Recurso extraordinário não conhecido." (STF, RE 100332/MG, Primeira Turma, Relator Ministro Rafael Mayer, julgamento em 01.06.1984).
} 
de que o valor do bem sofresse a avaliação da época da liberalidade, sendo, daí para frente, devidamente corrigido. Com a inflação que sucedeu à vigência do Código, alguma forma de correção monetária deveria ser feita, sob pena de se tornar ineficaz a norma. E o recurso encontrado pelos aplicadores da lei foi a atualização monetária (não mercadológica) do valor do bem doado.

Em sentido contrário ao estabelecido pelo CPC, o Código Civil de 2.002, em seu artigo 2.004, retomou a ideia do antigo artigo 1.792, quando estabelece: "O valor de colação dos bens doados será aquele, certo ou estimativo, que lhes atribuir o ato de liberalidade" (grifamos) ${ }^{77}$.

Diante disto, o novo Código Civil revogou o artigo 1.014, do $\mathrm{CPC}^{78}$.

Surpreendentemente, vigoram atualmente as duas fórmulas para apurar o valor das doações.

\footnotetext{
77 “Inventário. Doação inoficiosa. 1-A doação de bem imóvel é negócio jurídico consensual, porque se aperfeiçoa com o acordo de vontades entre doador e donatário, independentemente da entrega da coisa. 2-A doação de pais aos filhos não segue a regra geral da inoficiosidade uma vez que o referido ato, na forma do artigo 1.171 do Código Civil de 1916, implica adiantamento de legítima. 3-Os donatários estão obrigados a conferir no inventário do doador, por meio de colação, os bens recebidos, pelo valor que lhes atribuir o ato de liberalidade ou a estimativa feita naquela época, para que sejam igualados os quinhões dos herdeiros necessários, conforme artigo 1792, § 10 do Código Civil de 1916". (TJRJ, Al n.o 2008.002.29830, Quinta Câmara Cível, Desembargador Relator Miltin Fernandes de Souza, julgado em 18.12.2008)
}

${ }^{78}$ Agravo de instrumento. Inventário e partilha. Doação. Bens excluídos do inventário. Colação. Valor dos bens colacionados. Conflito de normas. Artigo 1.014, parágrafo único, do Código de Processo Civil e artigo 2.004, do Código Civil. Direito intertemporal. Inteligência do art. 1.787, do Código Civil. Doação inoficiosa. Inocorrência. 1 - 0 autor da herança pode dispor de seus bens em vida desde que observe a porção disponível do seu patrimônio. 2 Os bens doados em vida devem ser colacionados para se igualar a legítima dos herdeiros necessários. 3 - O Código de Processo Civil, artigo 1.014, parágrafo único, dispõe que os bens devem ser colacionados no valor que tiverem ao tempo da abertura da sucessão, ao passo que o Código Civil, artigo 2.004, estabelece que os bens colacionados devem ser computados pelo valor existente à época da liberalidade. 4 - Diante do conflito de normas aplica-se a regra de direito intertemporal do artigo 1.787, do Código Civil, segundo a qual aplica-se a lei vigente ao tempo da abertura da sucessão. Logo, se a morte do autor da herança ocorreu após a vigência do novo Código Civil, aplica-se para a colação a regra do artigo 2.004 do Código Civil, devendo os bens doados em vida serem colacionados pelo valor correspondente ao tempo da liberalidade. 5 - Caracteriza-se a doação inoficiosa se os bens doados ultrapassarem a quota que o doador, no momento da liberalidade, poderia dispor em testamento, o que não ocorre no caso vertente, visto que ao tempo da doação os bens transferidos não ultrapassavam a metade do patrimônio do doador. Agravo conhecido e desprovido. (TJGO, Al 97480-06.2010.8.09.0000, Relator Desembargador Fausto Moreira Diniz, decisão publicada em 13.10.2010) 
O Novo Código Civil, para efeito de compensação, adota o critério do valor à época da liberalidade (CC, arts. 2.003, § único; 2.004, § 1ㅇ; 2.005 e 2.007, § 1ㅇ). Não se pode esquecer a questão sobre a atualização ou correção monetária do valor dos bens colacionados desde a data da doação até o óbito. Apesar do silêncio do Código Civil, faz-se imperioso, em época inflacionária, a referida atualização ou correção, para que seja respeitado o princípio da igualdade da legítima e o objetivo da colação de evitar o desfalque na quota legitimária, que deve ser partilhada igualmente entre os herdeiros necessários.

Por outro lado, em caso de necessidade de redução da doação, toma por base o valor que o bem possui quando da data de abertura da sucessão, conforme dispõe o artigo 2.007, $\S$ 2o, do Código Civil: "A redução da liberalidade far-se-á pela restituição ao monte do excesso assim apurado; a restituição será em espécie, ou, se não mais existir o bem em poder do donatário, em dinheiro, segundo o seu valor ao tempo da abertura da sucessão, observadas, no que forem aplicáveis, as regras deste Código sobre a redução das disposições testamentárias" (grifamos).

Resumindo: para efeito de compensação, que é a regra geral, o Código Civil adota como parâmetro para apurar o valor do bem, a data em que a doação foi realizada, é claro, com a devida correção monetária (arts. 2.003, § único e 2.004, CC). Este sistema só é quebrado em caso de redução, que exige a restituição do excesso em espécie ou segundo o valor ao tempo da abertura da sucessão (art. 2.007, § 2으, CC).

O exemplo seguinte facilita a compreensão da regra geral do artigo 2.004, do Código Civil. A deixou dois filhos, B e C. Na década de 60, A doou para B uma casa em Santa Teresa, avaliada à época em $\mathrm{R} \$ 1.000 .000,00$ (um milhão de reais) e doou para $\mathrm{C}$ uma casa no Leblon, avaliada à época em 100.000,00 (cem mil reais). É cediço que, com o decorrer dos anos, os imóveis situados no bairro de Santa Teresa se desvalorizaram vertiginosamente, em decorrência do processo de favelização da área, ao passo que os imóveis no Leblon se tornaram os mais caros da cidade. Entretanto, apesar da mudança de preço com o decorrer do tempo, 
falecendo A no ano de 2.010, deverá ser seguida a regra da colação do valor dos bens à época da doação, obviamente, com a devida correção monetária. 


\section{Capítulo XIII - Aspectos Processuais da Colação.}

A lei civil impõe o dever de conferir as doações, e o Código de Processo Civil traz as diretrizes estabelecendo o momento de se revelarem as doações, ou oferecendo caminhos processuais se for mantida a recusa de colacionar.

O herdeiro que recebeu os bens por doação tem o dever de trazê-los à colação. O artigo 1.014, do Código de Processo Civil estabelece que o prazo para colacionar é aquele do artigo 1.000, referente as primeiras declarações, devendo o favorecido conferir por termo nos autos os bens recebidos: "No prazo estabelecido no art. 1.000, o herdeiro obrigado à colação conferirá por termo nos autos os bens que recebeu ou, se já não os possuir, trar-lhes-á o valor" $^{79}$.

Primeiramente, faz-se mister lembrar que o prazo do artigo 1.000 é de 10 (dez) dias, contado a partir da citação procedida após a apresentação das primeiras declarações, cuja contagem inicia no dia seguinte à juntada do mandato nos autos. Depreende-se da regra que o prazo para falar sobre as primeiras declarações também constitui o prazo para a colação. Independentemente de interpelação judicial deve comparecer o herdeiro, e executar a colação. Em tese, a simples citação, ou cientificação de que iniciou o inventário, seria suficiente para o comparecimento nos autos e comunicar as liberalidades ou favores.

Este prazo é para tão somente declarar as doações. Não para conferir - o que se dará posteriormente, com as avaliações ou perícias, momento em que se chegará ao valor total do patrimônio hereditário e dos bens transferidos aos herdeiros antes do falecimento do de cujus.

\footnotetext{
${ }^{79}$ Código de Processo Civil, artigo 1.000: “Concluídas as citações, abrir-se-á vista às partes, em cartório e pelo prazo comum de 10 (dez) dias, para dizerem sobre as primeiras declarações. Cabe à parte: I - argüir erros e omissões; II - reclamar contra a nomeação do inventariante; III - contestar a qualidade de quem foi incluído no título de herdeiro. Parágrafo único. Julgando procedente a impugnação referida no $\mathrm{n}$ I I, o juiz mandará retificar as primeiras declarações. Se acolher o pedido, de que trata o $\mathrm{n}^{\circ} \mathrm{II}$, nomeará outro inventariante, observada a preferência legal. Verificando que a disputa sobre a qualidade de herdeiro, a que alude o $\mathrm{n}^{\circ} \mathrm{III}$, constitui matéria de alta indagação, remeterá a parte para os meios ordinários e sobrestará, até o julgamento da ação, na entrega do quinhão que na partilha couber ao herdeiro admitido".
} 
Silenciando, porém, o herdeiro, ordena o juiz que venham as colações devidamente descritas. Qualquer herdeiro necessário provocará o incidente, requerendo a citação do obrigado a colacionar ${ }^{80}$. Todavia, ao receber a citação, é de costume que o herdeiro dirija-se aos autos do inventário e se oponha a conferência dos bens, sob algum fundamento que justifique a causa de exclusão de sua responsabilidade, como a finalidade remuneratória da doação, a dispensa de colação e o não recebimento dos bens.

O prazo para defesa e justificativa da recusa é de 10 (dez) dias, conforme dito anteriormente.

Analisando o teor da recusa, o juiz mandará ouvir as partes em 5 (cinco) dias. Proferirá, a seguir, a decisão, conforme o artigo 1.046, do Código de Processo Civil.

Compete ao juiz decidir em conformidade com os elementos que estão no processo. Somente se justifica remeter as partes às vias ordinárias quando envolver questão de alta indagação, isto é, se houver necessidade de produção de prova ampla. Diante disto, remeterse-á o caso para processo com um, porque, como se sabe, a cognição no procedimento de inventário não é plena.

Uma vez proferida a decisão, definindo se é ou não caso de colação, intimam-se todos os interessados, no lapso de tempo de 5 (cinco) dias.

\footnotetext{
${ }^{80}$ Recurso especial. Civil. Direito das sucessões. Processo de inventário. Distinção entre colação imputação. Direito privativo dos herdeiros necessários. llegitimidade do testamenteiro. Interpretação do art. 1.785 DO CC/16. 1. O direito de exigir a colação dos bens recebidos a titulo de doação em vida do "de cujus" é privativo dos herdeiros necessários, pois a finalidade do instituto é resguardar a igualdade das suas legítimas. 2. A exigência de imputação no processo de inventário desses bens doados também é direito privativo dos herdeiros necessários, pois sua função é permitir a redução das liberalidades feitas pelo inventariado que, ultrapassando a parte disponível, invadam a legítima a ser entre eles repartida. 3. Correto o acórdão recorrido ao negar legitimidade ao testamenteiro ou à viúva para exigir a colação das liberalidades recebidas pelas filhas do inventariado. 4. Doutrina e jurisprudência acerca do tema. 5. Recursos especiais desprovidos. (STJ, Resp 167.421, Relator Ministro Paulo Tarso Sanseverino, Terceira Turma, julgado em 7.12.2010)
} 
O recurso cabível para modificar a sentença é o agravo de instrumento ${ }^{81}$.

Declarada improcedente a oposição ao pedido de colacionar, incumbe que se tragam os bens em 5 (cinco) dias, sob pena de sequestro (CPC, art. 1.016, § 1으).

A busca dos bens não trazidos à colação é feita por meio da ação de sonegados. Dispõem de legitimidade para a demanda os herdeiros e o inventariante. Além destes, também o Ministério Público pode propor a ação quando houver interesse de menor ou incapaz.

O herdeiro obrigado à colação e demandado ficará, em princípio, sem receber o seu quinhão, até que se resolva a lide que trata da obrigação de colacionar. Mas, preferindo o quinhão, ser-lhe-á entregue desde que prestada caução correspondente ao valor do bem (CPC, art. 1.016, § 2으).

81 Código de Processo Civil, artigo 1.016: "Se o herdeiro negar o recebimento dos bens ou a obrigação de os conferir, o juiz, ouvidas as partes no prazo comum de 5 (cinco) dias, decidirá à vista das alegações e provas produzidas. $\S 1^{\circ}$ Declarada improcedente a oposição, se o herdeiro, no prazo improrrogável de 5 (cinco) dias, não proceder à conferência, o juiz mandará seqüestrar-lhe, para serem inventariados e partilhados, os bens sujeitos à colação, ou imputar ao seu quinhão hereditário o valor deles, se já os não possuir. § $2^{\circ}$ Se a matéria for de alta indagação, o juiz remeterá as partes para os meios ordinários, não podendo o herdeiro receber o seu quinhão hereditário, enquanto pender a demanda, sem prestar caução correspondente ao valor dos bens sobre que versar a conferência." 


\section{Conclusão.}

A colação é o ato pelo qual os herdeiros descendentes de mesma classe, que concorrem à sucessão do ascendente comum, reúnem ao monte partível quaisquer liberalidades que dele em vida receberam, sob pena de sonegados, para que sejam conferidas e igualadas as respectivas legítimas (CC, arts. 2.002 e 2.003).

No direito sucessório brasileiro, o princípio norteador é o da igualdade das legítimas. A colação tem como finalidade justamente igualar as partes legítimas que, em determinado momento, se tornaram desiguais por força de doação feita pelo ascendente a descendente

Com o intuito de justificar a exigência da colação, a doutrina elenca diversos fundamentos. Este trabalho deixou claro que de todas as teorias expostas, as que melhor servem ao direito pátrio são a da igualdade entre os descendentes e a da antecipação da herança.

Quanto à natureza da colação, vimos que prevalece entre os doutrinadores a opinião de que esta se funda na obrigação imposta legalmente ao herdeiro necessário de restituir ao monte-partível as liberalidades que recebeu do ascendente doador quando este ainda era vivo.

No direito pátrio a colação possui três pressupostos. (i) A colação é cabível apenas na sucessão legítima; (ii) Existência de co-herdeiros necessários, descendentes; (iii) A ocorrência de uma liberalidade feita em vida, pelo ascendente, em favor de descendente ou do cônjuge sobrevivente. 
A regra geral é que todas as liberalidades ao descendente, feitas em vida pelo inventariado, sejam levadas à colação. Entretanto, não é absoluta a presunção de que todas estas doações possuem o caráter de adiantamento de legítima.

São dispensadas da colação as doações que o doador determinar que saiam da parte disponível, contanto que não a excedam, computando-se este valor ao tempo da doação. Além disso, por força do parágrafo único, do artigo supracitado, ampliou-se a incidência de dispensa de colação à liberalidade feita em favor de descendente, que ao tempo da doação, não seria chamado à sucessão na qualidade de herdeiro necessário (art. 2005, CC). Apesar de não haver forma específica, entende a doutrina majoritária que deve ser expressa a determinação do testador no sentido de que a doação sairá da parte disponível.

A Lei vigente no Brasil não impõe o dever de colação a todos os sucessores necessários, mas, tão somente, aos filhos, ao cônjuge sobrevivente, aos netos (quando representarem seus pais na herança do avô, o mesmo que seus pais teriam que colacionar), aos bisnetos etc. 0 preceito compulsório aplica-se a quaisquer descendentes que sejam herdeiros legítimos e concorram à sucessão de ascendente comum. Conforme dito, a colação tem como escopo a igualação da legítima dos herdeiros necessários.

Somente os herdeiros necessários podem pedir a colação de bens recebidos por outros descendentes ou pelo cônjuge sobrevivente, embora o favorecido com a liberalidade deva conferi-la independentemente de interpelação judicial.

No curso desta obra, vimos que, em tese, todas as doações e liberalidades feitas, em vida, por ascendente, em favor de descendente ou do cônjuge sobrevivente devem ser colacionadas. Entretanto, existem alguns casos em que certas liberalidades são dispensadas de colação, como, por exemplo, as despesas ordinárias de ascendente com descendente, enquanto menor. 
Vimos no capítulo XI que existem dois modos de realização da colação. Surpreendentemente, o Código Civil de 2.002 parece adotar as duas teorias. Prevalece na doutrina a teoria da estimação e só alternativamente a da substância.

Em regra, a colação se faz pelo valor das doações (CC, art. 2.002), ou seja, o valor certo ou estimado que conste do ato de liberalidade (CC, art. 2.004). Se não constar o valor, estimase o que valia naquela época (CC, art. 2.004, $\S 10$ ). Por sua vez, a teoria da colação por substância ou in natura é utilizada, de forma excepcional, nos seguintes casos: (i) quando não houver no monte bens suficientes para igualar a legítima dos descendentes ou do cônjuge sobrevivente (CC, art. 2.003, § único). (ii) quando for constatada que a doação é inoficiosa, a restituição do excesso será em substância (CC, art. 2.007, §2ํ).

Outra importante questão aqui apresentada é a que se refere ao valor dos bens doados. Analisamos que para efeito de compensação, que é a regra geral, o Código Civil adota como parâmetro para apurar o valor do bem, a data em que a doação foi realizada, é claro, com a devida correção monetária (arts. 2.003, § único e 2.004, CC). Este sistema só é quebrado em caso de redução, que exige a restituição do excesso em espécie ou segundo o valor ao tempo da abertura da sucessão (art. 2.007, § 2ㅇ, CC).

Por fim, diante da análise profunda do instituto, pode-se constatar a grande importância do mesmo, qual seja, ele é o instrumento que garante a igualdade das legítimas dos herdeiros necessários. Então, este trabalho espera ter cumprido seu objetivo precípuo, que é destrinchar minuciosamente o instituto da colação, contribuindo, assim, para sua melhor exegese e aplicação prática. 


\section{Bibliografia}

Amorim, Sebastião e Oliveira, Euclides de. Inventários e Partilhas - Direito das Sucessões Teoria e Prática. 14ạ Ed. Editora Universidade do Direito. São Paulo. p. 235.

Dias, Maria Berenice. Manual das Sucessões. 2a Ed. São Paulo. Editora Revista dos Tribunais. 2011. pgs. 592, 593, 594, 597, 599 e 607.

Gomes, Orlando. Sucessões. Rio de Janeiro. 14ạ Ed. Editora Forense, 2008. pgs. 288, 289, 291, 292 e 295.

Gonçalves, Carlos Roberto. Direito Civil Brasileiro, volume 7. São Paulo. 5a Ed. Editora Saraiva, 2011. pgs. 538, 539 e 540.

Maximiliano, Carlos. Direito das Sucessões, volume III. 2a Ed. Rio de Janeiro: Livraria Editora Freitas Bastos, 1943. pgs. 423, 432, 441, 442, 448, 453, 455, 456 e 462.

Oliveira Leite, Eduardo de. Comentários ao Novo Código Civil - Do Direito das Sucessões. 5a Ed. Rio de janeiro. Editora GEN/Forense. 2009. pgs. 334, 337, 914, 916, 925, 928 e 934.

Rizzardo, Arnaldo. Direito das Sucessões. 6a Ed. Rio de janeiro. Editora GEN/Forense. 2011. pgs. $642,643,644,648,654,655$ e 656.

Rodrigues, Sílvio. Direito Civil, Direito das Sucessões, Volume 7. 26a Ed. Saraiva, 2003. pgs. 308 e 317.

Silva Pereira, Caio Mário. Instituições de Direito Civil, Volume VI. 18a Ed. Rio de Janeiro: GEN/Editora Forense, 2010. pgs. 372, 373, 374, 376, 377 e 379. 
Tartuce, Flávio e Simão, José Fernando. Direito Civil: Direito das Sucessões, vol. 6. 1a Ed. Rio de janeiro. Editora GEN/Forense. 2007. p. 413.

Venosa, Sílvio de Salvo. Direito Civil, Direito das Sucessões volume 7. São Paulo. 4a Ed. Editora Atlas, 2004. pgs. 308 e 309. 